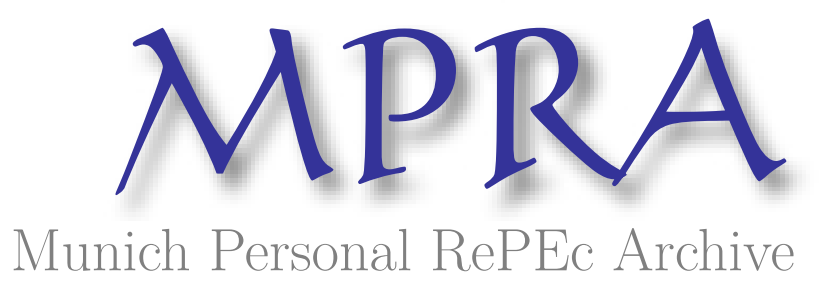

\title{
Trust in government and its effect on preferences for income redistribution and perceived tax burden
}

Yamamura, Eiji

3 July 2012

Online at https://mpra.ub.uni-muenchen.de/39833/

MPRA Paper No. 39833, posted 05 Jul 2012 09:45 UTC 


\title{
Trust in government and its effect on preferences for income redistribution and perceived tax burden
}

\author{
Eiji Yamamura ${ }^{1}$
}

Department of Economics, Seinan Gakuin University, 6-2-92 Sawaraku Nishijin, Fukuoka 814-8511, Japan

\begin{abstract}
This paper explores how a trust in government shared by neighbors is associated with individual preferences for income redistribution and individual perceptions regarding income tax burden. Three measures for trust in government are used: "trust in ministries and government agencies", "trust in diet members", and "trust in members of municipal councils". After controlling for individual characteristics, the key findings are: (1) people are more likely to express preferences for income redistribution when trust in government in their residential area is high; (2) people are more likely to perceive their tax burden as low when trust in government in their residential area is high; and (3) when the sample is divided into high- and low-income earners, these results are only clearly observed for high-income earners and not low-income earners.
\end{abstract}

JEL classification: D30; D63, H20, Z13

Keywords: Trust in government; Redistribution; Perception of tax; Inequality

${ }^{1}$ Department of Economics, Seinan Gakuin University, 6-2-92 Sawara-ku, Fukuoka 814-8511, Japan. E-mail address: yamaei@seinan-gu.ac.jp 


\section{Introduction}

Researchers have paid significant attention to the influence of shared societal values on individual's perceptions regarding redistribution and the welfare state (e.g., Gordon, 1989; Wenzel, 2004; 2005a; 2005b; Klor and Shayo, 2010; Feld and Frey, 2002; 2007; Luttens and Valfort, 2011). For instance, the degree of trust is found to play a key role when tax systems are considered. The greater the level of generalized trust in others, the more likely it is that people will pay tax (Scholz and Lubell, 1998). Trust in institutional conditions such as government and politics make a substantial contribution to establish tax morale and deter tax evasion (Scholz and Pinney, 1995; Torgler, 2003; Hammar et al., 2009). Trust and confidence in such institutions lead people to prefer the welfare state (Algan et al., 2011) and pay tax (Oh and Hong, 2012). Consequently, the size of the welfare state is determined partly by the level of social trust (Bergh and Bjørnskov, 2011).2 Recently, the seminal work of Algan et al. (2011) showed that there is a "non monotonous relationship between trust and the generosity of the welfare sates in OECD countries" (Algan et al., 2011, p. 1). That is, countries with low trust in the government can have a high public expenditure rate, as do countries with high trust in their government. In contrast, countries with medium levels of trust have low public expenditure rates. Algan et al. (2011) considered Anglo-Saxon countries and Japan to have a medium level of trust, resulting in limited welfare states.

Within a country, there is a wide variation of income, education level, and generation. Hence, there is the possibility that the effect of trust on preference for a welfare state varies according to individuals' demographic groups. Concerning the findings of Algan et al. (2011), a question naturally arises: does a medium level of trust lead people to prefer a smaller welfare state in Anglo-Saxon countries and Japan? As suggested by Alesina et al. (2004), in the United States inequality decreased high-income earners' levels of happiness while inequality did not decrease low-income earners' happiness. Hence, perceptions regarding redistribution and welfare states appear to differ between high- and low-income earners in countries with medium levels of trust. Based on data from Japan, Yamamura (2012b) presented evidence that community participation differently influences preferences for redistribution between high- and low-income groups. Therefore, in Anglo-Saxon countries and Japan, the different effects of trust

2 Yamamura (2012a) explored the opposite causality concerning how the size of government influences the level of trust. 
between high- and low-income earners are possibly neutralized. To determine any policy implications, analyzing the role of trust in government rather than generalized trust is a more concrete and suggestive method. ${ }^{3}$ Thus, it is worthwhile to investigate the effect of trust in government on the generosity of the welfare state in countries with medium levels of trust. A large number of researchers have explored how and why people prefer income redistribution (e.g., Ravallian and Lokshin, 2000; Corneo and and Gruüner, 2002; Alesina and La Ferrara, 2005; Rainer and Seidler, 2008; Alesina and Giuliano, 2009; Klor and Shayo, 2010). However, no studies have attempted to compare the effect of trust in government on the preference for redistribution between different income groups. ${ }^{4}$

In addition to preference for redistribution, researchers have attempted to assess the determinants of perceptions regarding tax (e.g., Cuccia and Carnes, 2001; Gemmel et al., 2003; 2004; Feld and Larsen, 2012). ${ }^{5}$ Both preference for redistribution and perceptions regarding tax are thought to be key factors in producing effective tax policy and efficient welfare states. However, subjective analysis is thought to be biased by various factors, including questionnaire construction and respondents' misunderstandings regarding questions about their subjective views. Therefore, it is important to re-examine findings about subjective views using other approaches (Algan et al., 2012). To show how and the extent to which estimation results for preference for redistribution are reliable, it is worthwhile to assess whether estimations of perceptions about tax are consistent with those for preference for redistribution. By jointly analyzing the role of trust on both preference for redistribution and perceived tax burden, I can provide evidence showing how trust systematically influences individuals' perceptions regarding policy on welfare state. In addition to preference for redistribution, the present paper also compares its effect on perceived tax burden between these groups.

For this purpose, the present paper used data from Japanese General Social Surveys (JGSS), which included more than 10,000 observations. Most existing

${ }^{3}$ Kumlin and Rothstein (2005) asserted that people infer others' trustworthiness from how they perceive public service bureaucrats.

${ }^{4}$ Recent studies have investigated the influence of political conditions on people's perceptions regarding, for example, trust and life satisfaction (Bjørnskov et al., 2007; 2008a; 2008b; Yamamura, 2012a). It was found that reducing economic inequality leads to an increase social trust (Rothstein and Uslaner, 2006).

5 Voters' perceptions of their income tax liabilities are systematically biased towards over-estimation (Gemmell, 2004). Overestimation of tax burden is negatively associated with preferences for redistribution. This association is, however, not statistically significant (Gemmell, 2003). 
papers are based on cross-country data or on data from countries with heterogeneous populations. Hence, identifying the effect of perceptions, for example perceptions of trust, is difficult. Japan is considered a more racially and culturally homogenous society than Western countries. Hence, the use of the JGSS allows me to naturally control for heterogeneity and therefore identify the effect of trust in government. The key findings of this paper via various specifications estimated by an ordered probit model are as follows: (1) people are more likely to express preferences for income redistribution in areas where neighbors tend to trust government; (2) people are more likely to perceive their tax burden as low in areas where neighbors tend to trust the government; and (3) when the sample is divided into high- and low-income earners, the first two results are observed only for high-income earners and not for low-income earners.

The remainder of this paper is organized as follows. In Section 2, testable hypotheses are discussed. Section 3 explains data and the empirical method used. Section 4 presents the estimation results and their interpretation. The final section offers some conclusions.

\section{Hypotheses}

According to the political economy model provided by Algan et al. (2012), "everybody wants more social benefits when he expects to be surrounded by more civic individuals, because there is less fraud on taxes and benefits and officials are more efficient" (Algan et al., 2021, p. 3). Opportunistic uncivic individuals find it difficult to hide their income and so evading income tax is less likely if there is trust in government-it is a sufficient incentive to deter tax evasion. That is, the probability of fraud on taxes seems to depend considerably on quality of government. If a government is more corrupt, then it is easier for people to evade paying tax. To put it differently, corrupt government reduces the cost for fraud on taxes and therefore increases the incidence of fraud on taxes, resulting in economic inefficiency. In this situation, people are apt to distrust government. Consequently, as suggested by the theoretical model of Oh and Hong (2012), people's distrust in government reduces the willingness to pay taxes. And eventually, individuals are less likely to prefer income redistribution.

If an individual's household income is higher than the average household income, then that individual is considered to belong to a high-income group. The remainder are regarded as relatively poor. Income tax is progressive tax in Japan. Hence, 
high-income earners are obliged to pay higher tax than low-income earners. In contrast, there is just a small tax burden for low-income earners. However, low-income earners can enjoy the benefit of income redistribution from high-income earners. Hence, the net social benefit from paying taxes is greater for low-income earners than for high-income earners. Further, even if others evade tax owing to distrust toward the government, the tax burden does not outweigh the benefit for low-income earners. Hence, low-income earners are less inclined to oppose redistribution policies. In contrast, high-income earners are more likely to oppose redistribution and are therefore less inclined to prefer redistribution policies. I advance Hypothesis 1:

\section{Hypothesis 1:}

Rich people are more inclined to prefer income redistribution when they live in an area where residents are more likely to trust government.

In Feld and Frey (2002; 2007), a psychological tax contract was determined on the condition that taxpayers and government treat each other with mutual respect and honesty. If government does not treat taxpayers as partners on an equal footing, taxpayers violate the contract and evade taxes. Tax complexity is associated with taxpayers' perceptions of equity when no explicit justification for its complexity and relative economic consequences is offered (Cuccia and Carnes, 2001). If government manipulates information and makes tax structures complex for the government's benefit, then taxpayers distrust government. If the government were to take such an attitude, which appears to be in contradiction to a fair tax system, then this would influence the perceptions of taxpayers (Fehr and Schmidt,1999; Galasso, 2003; Alesina and Angeletos, 2005). In this situation, people perceive that the tax taken is used for the benefit of the government rather than for society as a whole. Hence, taxpayers perceive their tax burden as high even if they have civic virtue. To put it differently, if taxes paid by people are used effectively and efficiently to maximize social welfare, taxpayers are unlikely to perceive their tax as high. This is especially so for high-income earners because income tax in Japan is progressive. Hence, I advance Hypothesis 2:

\section{Hypothesis 2:}

Rich people are more inclined to perceive their tax burden as low when they live in an area where residents are more likely to trust government. 


\section{Data and Methods}

\subsection{Data}

JGSS data, which provided individual-level data, are used in the present paper. ${ }^{6}$ JGSS have been conducted since 2000 and were designed as a Japanese counterpart to the General Social Survey data collected in the United States. A two-stage stratified sampling method was used. The JGSS is conducted throughout Japan and its respondents are adults aged between 20 and 89 years. This paper used a dataset covering 2000, 2001, 2002, 2003, 2005, 2006, and 2008. ${ }^{7}$ JGSS respondents were asked standard questions via face-to-face interviews concerning their individual characteristics. From JGSS, researchers can obtain information relating to preferences regarding income redistribution policies, perceived tax burden, trust in government and politics, marital and demographic (age and gender) status, annual household income, ${ }^{8}$ years of schooling, age, prefecture of residence, and prefecture of residence at 15 years of age. A Japanese prefecture is the equivalent to a state in the United States or a province in Canada. There are 47 prefectures in Japan, and the average value of the variables included in the JGSS can be calculated for each prefecture.

Previous studies have highlighted the significant influence of cultural and social background on "happiness" (Alesina et al., 2004), as well as their influence on individual preferences for income redistribution (Luttmer, 2011). When comparing within-country analysis and comparative analysis between different countries, "within country analysis is much less likely to be subject to measurement error due to changes in institutional structures of redistributive policies" (Alesina and Giuliano 2009, p. 22). Concerning this point, the use of JGSS data in this paper has a certain advantage. Trust level is inevitably influenced by historical and cultural

${ }^{6}$ Data for this secondary analysis, "Japanese General Social Surveys (JGSS), Ichiro Tanioka," were provided by the Social Science Japan Data Archive, Information Center for Social Science Research on Japan, Institute of Social Science, the University of Tokyo.

7 Surveys were not conducted in 2004 and 2007. Surveys were conducted in 2009 and 2010 but the data are not available.

8 In the original dataset, annual earnings were grouped into 19 categories, and it was assumed in this study that everyone in each category earned the midpoint value. For the top category of " 23 million yen and above", it was assumed in this study that everybody earned 23 million yen. Of the 11,808 observations used in the regression estimations, there were only 116 observations in this category. Therefore, the problem of top-coding should not be an issue here. 
background, which is difficult to completely control. Therefore, the estimation results of Algan et al. (2011), based on cross-country data, seem to suffer from endogeneity bias. In contrast, Japan shares a common historical and cultural background. Therefore, JGSS data enabled comparisons between the influence of trust on individuals' views regarding redistribution policy and tax burden under the same historical and cultural conditions.

The variables used in the regression estimations are shown in Table 1, which provides definitions and basic statistics (i.e., mean, standard deviation, maximum and minimum value).

Concerning trust in government and politics, the relevant JGSS questions asked:

"How well do you trust ministries and government agencies?"

"How well do you trust diet members?"

"How well do you trust members of municipal councils?"

Concerning these questions, respondents could choose one of three responses: "Not very much" (assigned a value of 1), "some" (assigned a value of 2) and "very much" (assigned a value of 3). Algan et al. (2012) used respondents' trust levels to explore the effect of trust on preference for the welfare state. In their theoretical model, the expectation to be surrounded by civic individuals played a key role. To directly examine their prediction, one must simply consider the type of individuals that actually surround the respondents (Shields et al., 2009). In addition, causality between the trust level and preference is ambiguous because the proxy for trust is considered an endogenous variable. That is, those who prefer a welfare state are possibly likely to trust the government. This inevitably causes endogeneity bias. To avoid endogeneity bias, following Yamamura (2012), the present paper uses trust level in residential area, rather than the individual's trust level. I calculated average values within each prefecture and used these values as measures of trust in government and politics.

Gini data coefficients for prefecture level household income were calculated using data from the "National Survey of Family Income and Expenditure", conducted by the Ministry of Internal Affairs and Communications (1999). These surveys are conducted every 5 years, e.g., 1999, 2004, and 2009. The data used in this paper cover the period 2000-2008. Therefore, as explained in the following section, I used Gini coefficients for 1999 as an initial value. The average household income within a prefecture (AVINCOM) is calculated based on JGSS data. The utility of people is thought to be affected not only by one's own income but also by 
the income level of neighboring people (e.g., Clark and Oswald, 1996; Luttmer, 2005). In other words, not only absolute income but also relative income is considered to be related to an individual's utility and, therefore, perceptions. In the present paper, both individual-level household income and average household income within residential prefectures are controlled for to capture the relative income effect. I matched the information regarding individual characteristics sourced from JGSS data with prefecture characteristics such as trust in government and politics proxies, Gini coefficients, and average income level. Thus, I was able to investigate how characteristics of residential area affect an individual's preference for income redistribution and perceived tax burden.

With respect to individual characteristics, EQUAL are proxies for preferences for income redistribution. A question from the JGSS asked: What is your opinion of the following statement? "It is the responsibility of the government to reduce the differences in income between families with high incomes and those with low incomes." There were five response options, ranging from "1 (strongly disagree)" to "5 (strongly agree)". EQUAL is the values that the respondents chose. Figure 1 demonstrates the distribution of views regarding political redistribution, and shows that the number of respondents who chose " 1 " or " 2 " is smaller than those who chose "4" or " 5 ". Thus, the shape of the histogram is skewed towards the right. The JGSS also asked the following question: "Do you think the amount of income tax you have to pay is high?" There were five response options: "1 (too low)", "2 (somewhat low)", "3 (about right)", "4 (somewhat high)", and "5 (too high)". TAX is the response options chosen by the respondents. The distribution of $T A X$ is illustrated in Figure 2. This tells that that most people considered tax as "somewhat high" or "too high". Figures 1 and 2 suggest that people are more likely to prefer redistribution and consider tax high. That is, people support redistribution policies if they are not obliged to pay tax, which is in line with the argument of expressive voting theory (e.g., Tullock,1971; Copeland and Laband, 2002; Sobel and Wagner, 2004; Hillman, 2010).

It is plausible to argue that political ideology is one of determinants concerning preferences for redistribution and so should be controlled for when preferences for income redistribution are estimated (Bernasconi, 2006; Alesina Giuliano, 2009). The JGSS also asked: "Where would you place your political views on a 5-point scale?" There are five response options: "1 (conservative)" to "5 (progressive)". Based on responses to that question, I constructed a proxy for capturing a political ideology effect. Political views are captured by dummies: PROG_5 takes the value of 1 when 
the response is “5”, otherwise 0 . PROG_1, PROG_2, PROG_3, and PROG_4 are defined in a similar manner.

As shown in Table 1, the average household income is 6.12 million yen. In the present paper, high-income earners are defined as those with a household income that is higher than 6 million yen, approximately the average household income. The remaining respondents are defined as low-income earners. The distribution of household income is illustrated in Figure 3, suggesting that the shape of the histogram is skewed to the left. People with a household income between 3 and 4 million yen are the most common income group. Hence, household income from 0 to 6 million yen covered both low- and medium-level income earners. Therefore, care should be called for concerning the classification between high- and low-income earners.

Table 2 shows differences between the key variables of the high- and low-income groups. The table shows that EQUAL for the low-income group is larger than for the high-income group by 0.31 on the 5 -point scale and is statistically significant at the $1 \%$ level. This is consistent with the expectation that poorer people are more likely to prefer income redistribution to increase their welfare. The value of TAX for the high-income group is larger by 0.05 on the 5 -point scale than the low-income group. Further, it is statistically significant at the 1\% level. The combined results of EQUAL and TAX can be interpreted to represent that low-income earners would accept the benefits from redistribution policies at the expense of burdens on high-income earners. Turning now to the proxies for trust in government and politics, the values for TRUST_MINIS and TRUST_MUNI for the low-income group are larger than for the high-income group, and are statistically significant at the 1\% level. This implies that low-income earners are more likely to live in areas where neighbors trust ministers, government agencies, and also municipal councils than are high-income earners.

\subsection{Econometric Framework and Estimation Strategy}

In Figures 4(a), (b), (c) and 5(a), (b), (c), the vertical axis shows the average preference for redistribution (EQAUL) within a prefecture. In Figures 6 (a), (b), (c) and $7(\mathrm{a}),(\mathrm{b}),(\mathrm{c})$, the vertical axis shows the average perceived tax burden (TAX) within a prefecture. In Tables 4(a), 5(a), 6(a), and 7(a), the horizontal rows show the average trust in ministers and government agencies (TRUST_MINIS) within a prefecture. In Tables 4(b), 5(b), 6(b), and 7(b), the horizontal rows show the average trust in diet members (TRUST_DIET) within a prefecture. In Tables 4(c), 5(c), 6(c) 
and $7(\mathrm{c})$, the horizontal line shows the average trust in members of municipal councils (TRUST_MUNI) within a prefecture. Results based on high-income earners are illustrated in Figures 4(a), (b), (c) and 6(a), (b), (c), while those for low-income earners are shown in Figures 5(a), (b), (c) and 7(a), (b), (c). A cursory examination of Figures 4(a), (b), and (c) reveal a positive association between preference for redistribution and trust in government and politics. In contrast, Figures 5(a), (b), and (c) do not show an obvious relationship. As for perceived tax burden, Figures 6(a), (b), and (c) reveal a negative relationship between perceived tax burden and trust in government and politics. In contrast, Figures 7(a), (b), and (c) show no relationship. These are congruent with the hypotheses raised previously. However, these relationships are observed when individual characteristics are not controlled for. A more precise examination calls for a regression analysis using individual-level data matched with characteristics from residential areas.

For the purpose of examining the hypotheses proposed the previous section, the estimated function of the baseline model takes the following form:

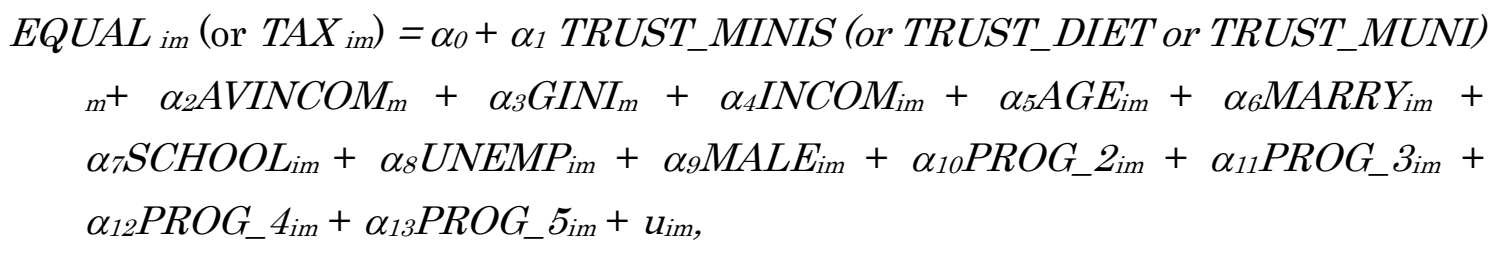
where $E Q U A L_{\text {im }}$ (or $T A X_{\text {im }}$ ) represents the dependent variable for individual $i$ and prefecture $m$. Regression parameters are represented by $\alpha$. As explained earlier, values for $E Q U A L$ and $T A X$ range from 1 to 5 and an ordered probit model is used to conduct the estimations. The error term is represented by $u_{i m}$. It is reasonable to assume that the observations may be spatially correlated within a prefecture, as the preference of one agent may well relate to the preference of another in the same prefecture. To consider such spatial correlation in line with this assumption, I used the Stata cluster command and calculated z-statistics using robust standard errors. The advantage of this approach is that the magnitude of spatial correlation can be unique to each prefecture.

As is exhibited in the correlation matrix of Table 3, the correlation coefficient between TRUST_MINIS and TRUST_DIET is 0.76 and statistically significant at the $1 \%$ level. The correlation coefficient between TRUST_MINIS and TRUST_MUNI is 0.72 and statistically significant at the $1 \%$ level. In addition, the correlation coefficient between TRUST_MUNI and TRUST_DIET is 0.83 and statistically significant at the $1 \%$ level. These suggest a strong correlation between 
the proxies for trust in government and politics. Therefore, multicollinearity occurs when these three variables are incorporated as independent variables at the same time. To avoid multicollinearity, one variable is incorporated when the other two are not. From Hypothesis 1, these proxies for trust in government are predicted to have the positive sign when EQUAL is the dependent variable. Further, from Hypothesis 2 , the proxies for trust in government are expected to have the negative sign when TAX is the dependent variable.

AVINCOM and GINI are included to capture the effects of relative income and income inequality within a prefecture. Luttmer (2005) argued that increases in average income within a locality lead to reductions in the residents' welfare. People are thought to support redistribution to improve their welfare. In the present paper, AVINCOM is expected to have the positive sign when the determinants of EQUAL are ascertained. What is more, in comparison with neighbors, individuals perceive their tax burden as high. AVINCOM is expected to have the positive sign when the determinants of TAX are ascertained. However, it is also plausible to assume that an increase in AVINCOM causes people to expect that they can also earn more. As suggested by the "prospect of upward mobility" (POUM) theory (Bénabou and Ok, 2001), people who expect to move up the income scale will not support a redistribution policy even if they are currently poor. Hence, the sign for AVINCOM may become negative when the determinants of EQUAL are assessed. Further, individuals perceive their tax burden as low and so the sign for AVINCOM may become negative when the determinants of TAX are assessed. If people wish to address inequality, the sign for GINI should be positive in the estimation where EQUAL is a dependent variable. The greater the income inequality, the more important paying taxes becomes for income redistribution. Hence, GINI is predicted to have the negative sign in the estimation for the determinants of TAX.

Following previous literature (e.g., Ravallian and Lokshin, 2000; Corneo and Gruüner, 2002; Ohtake and Tomioka, 2004; Alesina and La Ferrara, 2005; Rainer and Seidler, 2008; Alesina and Giuliano, 2009; Yamamura, 2012), the present paper used INCOME, AGE, MARRY, SCHOOL, and MALE as independent variables to control for individual characteristics. The generosity of the welfare state appears to depend not only on economic conditions but also on individuals' political views. For the purpose of capturing political views, PROG_2-PROG_5 are included and PROG_1 (conservative view) is the reference group. Liberal views are generally considered to support left-wing policies such as political income redistribution. Accordingly, the coefficients of PROG_2-PROG_5 are predicted to take the positive 
sign, with the absolute value of the coefficient PROG_5 to be largest among them.

\section{Estimation Results}

The estimation results concerning EQUAL are exhibited in Tables 4 and 5, and the results for TAX are shown in Tables 6 and 7. Luttmer (2005) pointed out that there is "the possibility that cross-section results are driven by selection of people who are happier by nature into areas that are relatively poor... One might worry that movers may have had something unobserved happen to them" (Luttmer, 2005, p. 977). This unobserved factor could cause estimation bias. The JGSS provided data regarding not only current residential prefectures but also the residential prefectures of respondents at 15 years of age. If the current residential prefecture is not the same prefecture at 15 years of age, respondents are defined as "movers". For the purpose of alleviating this bias, following Luttmer (2005), I also conducted estimations that excluded all respondents who had moved to a different prefecture. Results based on samples of "non-movers" and "movers" are exhibited in Tables 4 and 6, and those based on samples excluding "movers" are in Tables 5 and 7. In each table, results of the specification with TRUST_MINIS, TRUST_DIET, and TRUST_MUNI are presented in columns (1)-(3), columns (4)-(6), and columns (7)-(9), respectively. Further, in each table, columns (1), (4), and (7) show results based on the full sample. After dividing the sample into high- and low-income groups, columns (2), (5), and (8) show results based on the high-income sample, and columns (3), (6), and (9) present those based on the low-income group.

In Table 4, the coefficients for TRUST_MINIS, TRUST_DIET, and TRUST_MUNI have the expected positive signs in all estimations. Further, they are statistically significant for the full sample results and the high-income sample, whereas they are not significant for results using the low-income sample. The coefficients of the proxies for trust in government, such as TRUST_MINIS, TRUST_DIET, and TRUST_MUNI exhibited in Table 4, cannot be interpreted as marginal effects and it is difficult to interpret them in the ordered probit model. Hence, to determine their economic significance, I need to determine their marginal effects. The values for EQUAL range between 1 and 5 and therefore the marginal effects of TRUST_MINIS, TRUST_DIET, and TRUST_MUNI vary according to the values of EQUAL ${ }^{9}$ (Greene, 2008, p. 831-835). In the rows below PROG_5, Table 4

9 The marginal effects of TRUST_MINIS, TRUST_DIET, and TRUST_MUNI can be calculated for each value of EQUAL. That is, their marginal effect on the probability 
shows the marginal effects of TRUST_MINIS, TRUST_DIET, and TRUST_MUNI on the probability that the value of EQUAL is 5 (respondents "strongly agree" with redistribution policy). They are statistically significant in the result columns using the full sample and the high-income sample. In columns (1) and (2), the absolute values of the marginal effects of TRUST_MINIS are 0.10 and 0.18 , respectively. This means that a 1-point increase on the 3-point scale for the average value that neighbors trust ministers and government agencies leads to a $10 \%(18 \%)$ increase in the probability that individuals (high-income individuals) "strongly agree" with redistribution policies. In columns (4) and (5), the absolute values of the marginal effect of TRUST_DIET are 0.16 and 0.33 , respectively. This means that a 1 -point increase on the 3-point scale for the average value that neighbors trust diet members leads to $16 \%(33 \%)$ increase in the probability that individuals (high-income individuals) "strongly agree" with redistribution policies. In columns (7) and (8), the absolute values of the marginal effects of TRUST_MUNI are 0.14 and 0.25 , respectively. This means that a 1-point increase on the 3-point scale for the average value that neighbors trust members of municipal council leads to $14 \%$ (25\%) increase in the probability that individuals (high-income individuals) "strongly agree" with redistribution policies. In short, the marginal effect of trust in government on preference for redistribution based on the high-income sample is approximately two times greater than that for the full sample.

Concerning the control variables shown in Table 4, AVINCOM produces the negative sign in all columns and is statistically significant for results using the full sample and the low-income sample. Interestingly, this implies that an increase in the average income leads low-income earners to be less inclined to support a redistribution policy. It follows from this that, as for redistribution policies, an increase in the average income is not related to poorer people's negative feelings but to positive feelings such as expectations of higher earnings. The coefficient sign of GINI is negative when using the full sample and the low-income sample, while the its sign is positive for the high-income sample. Furthermore, GINI is statistically significant only for the high-income sample. This suggests that income inequality increases the incentive to support redistribution policies for rich people rather than for low-income earners. With respect to individual characteristics, the coefficient of INCOME has the negative sign in all estimations, and is not statistically significant

that EQUAL is 5, their marginal effect on the probability that EQUAL is 4, their marginal effect on the probability that EQUAL is 3, their marginal effect on the probability that EQUAL is 2, and their marginal effect on the probability that EQUAL is 1 . 
for the low-income group. This implies that a reduction in income through a policy of income redistribution provides rich people the incentive to oppose such a policy. The coefficient of SCHOOL has the negative sign and is statistically significant at the $1 \%$ level. This result is considered to reflect that people with higher education are more likely to expect higher future earnings. UNEMP takes the positive sign in all estimations, but is only statistically significant for the full sample and the high-income sample, implying that the effect of job status on preference for redistribution is ambiguous. In line with expectations, a positive sign for PROG_5 is observed in all estimations. This suggests that political views affect preferences for redistribution.

Results reported in Table 5 are similar to those in Table 4. With respect to key variables for the high-income sample, TRUST_MINIS, TRUST_DIET, and TRUST_MUNI continue to show the predicted positive sign and are statistically significant. In contrast, for the low-income sample, they are not statistically significant with the exception of TRUST_MUNI, although they exhibit the positive sign. In other words, only TRUST_MUNI has a statistically significant positive effect on individuals' preferences for redistribution for both the high- and low-income groups. As for marginal effects, the magnitude of TRUST_MINIS, TRUST_DIET, and TRUST_MUNI are very similar, as exhibited in Table 4. Thus, the effect of trust in government on preference for redistribution is more clearly observed for high-income earners than low-income earners. This is congruent to Hypothesis 1.

I now turn to Table 6, which exhibits the results of the estimations regarding the perceived tax burden. With respect to the key variables, the coefficient signs for TRUST_MINIS, TRUST_DIET, and TRUST_MUNI produce the expected negative signs, with the exception of columns (6) and (9). What is more, they are statistically significant in columns (1), (2), (5), and (8). This suggests that trust in government leads high-income earners to perceive their tax burden as low but this is not true for low-income earners. Concerning their marginal effect, as presented in the rows below PROG_5, Table 6 shows the marginal effect of TRUST_MINIS, TRUST_DIET, and TRUST_MUNI on the probability that the value of TAX is 5 (respondents perceive their tax burden as "too high"). For the high-income group, the marginal effects of TRUST_MINIS, TRUST_DIET, and TRUST_MUNI are $-0.29,-0.47$, and -0.39 , respectively. These are interpreted as follows: a 1-point increase on the 3 -point scale for the average value that neighbors trust ministers and government agencies leads to a $29 \%$ decrease in the probability that high-income individuals 
perceive their tax burden as "too high". A 1-point increase on the 3-point scale for the average value that neighbors trust diet members leads to a $47 \%$ increase in the probability that high-income individuals perceive their tax burden as "too high". A 1-point increase on the 3-point scale for the average value that neighbors trust members of municipal councils leads to $39 \%$ increase in the probability that high-income individuals perceive their tax burden as "too high".

As for control variables, the coefficients of AVINCOM and GINI are not statistically significant in all columns. Considering the results of Tables 4 and 6 jointly reveals that residential economic conditions such as AVINCOM and GINI influence preferences for redistribution but do not affect perceived tax burden. The reason that the effect of GINI on preference for redistribution differs from that on perceived tax is partly explained by expressive behavior (Hillman, 2010). The expressive voting hypothesis states that people vote for a certain policy despite the fact that the actual implementation of the policy would reduce their material utility. This is because individuals vote to express their views regarding particular issues, but they do not intend to affect the outcomes of the election (e.g., Tullock, 1971; Copeland and Laband, 2002; Sobel and Wagner, 2004). Expressions of support for income redistribution by rich people can be considered as suggesting their support for the generosity of the welfare state, which increases the utility of rich people. However, in expressing their perceptions regarding their tax burden, rich people are less likely to show their support for such generosity. Estimations in the present paper have been based on survey data. Survey responses are likely to be interpreted as expressive because the responses do not affect redistribution policy in any way. That is, there is expressive utility from signaling conformity with group-defined norms of generosity regarding the welfare state but there is no material loss from expressing a preference for income redistribution (Tullock, 1971).

Turning to individual characteristics, INCOM yields the positive sign for the full sample and the high-income sample, and is statistically significant at the $1 \%$ level. However, it yields the negative sign for the low-income sample and is not statistically significant. This is thought to reflect that income tax in Japan is progressive. Combined results for the effect of INCOM on preference for redistribution and perceived tax burden are in line with the expectation. SCHOOL produces the negative sign in all columns. After dividing the sample into high- and low-income groups, it is interesting to observe that SCHOOL is statistically significant at the $1 \%$ level only for the low-income group. This can be interpreted as implying the following: the higher an individual's education level, the more they will 
earn even if they currently belong to a low-income group. Where the expected income is higher than the current income, low-income earners with higher education will perceive their current tax burden as low. In contrast, high-income earners have already enjoyed the returns from investments in human capital, and the probability that they will earn more in the future is low. Therefore, they do not perceive their tax burden as low. This is in line with the POUM hypothesis (Bénabou and Ok, 2001; Alesina and La Ferrara, 2005; Rainer and Siedler, 2008). The positive sign of PROG_3-PROG_5 is statistically significant in columns (1)_(9). This shows that the more liberal people are, the greater they perceive their tax burden. In my interpretation, liberal people are more likely to consider that the government manipulates information to increase tax for the government's interest at the expense of the citizen's burden. Hence, the level of tax to be paid is higher than the ideal amount.

The results of Table 7 are very similar to those in Table 6 , meaning that the effect of government in trust on perceived tax burden is robust after controlling for endogeneity bias.

To sum the various estimated results presented thus far, I conclude, as a whole, that the estimation results examined in this section are consistent with Hypotheses 1 and 2 , and support them reasonably well.

\section{Conclusions}

Civic virtue and perception are found to influence the outcomes of economic policy and therefore the effectiveness of economic policy (Aghion et al., 2010; Algan and Cahuc, 2009; Algan et al., 2012). However, the majority of previous studies on these issues are based on cross-country data or data from countries with heterogeneous populations. Hence, identifying the effect of perceptions such as trust is difficult. The present paper used data from Japan, a society considered as more racially and culturally homogenous than Western countries. Hence, the identification of the effect of trust is more convincing here than in previous research. The present paper examines the effect of trust in government on individual preferences for income redistribution and individual perceptions regarding income tax burden. The key findings are summarized as follows: people are more likely to express preferences for income redistribution and to perceive their tax burden as low when their neighbors are more inclined to trust government. When the sample is divided into high- and low-income earners, these results are only clearly observed for high-income earners and not low-income earners. 
The main contribution of the present paper is twofold: First, the effect of trust in government on views regarding the welfare state varies according to income group even when respondents share the same cultural and historical background. Algan et al. (2012) assumed that individuals are categorized into two types, either civic or uncivic, in an attempt to explain the non-monotonic relationship between trust and generosity of welfare states. However, in their regression estimations to explore the determinants of generosity of welfare states, the difference between civic and uncivic individuals was not directly assessed. The present paper, following Alesina et al. (2004) and Yamamura (2012), sheds light on differences in income levels to investigate how trust in government affects perceptions regarding the welfare state. The present paper shows clear differences between high- and low-income groups. Second, considering the determinants for preference for redistribution and perceived tax burden established that trust has a more systematic effect on perceptions regarding the welfare state than those suggested in existing literature.

As mentioned above, Japan is generally characterized as a racially homogenous society. Aside from such homogeneity, Japan's historical and cultural backgrounds also distinguish it from Western countries. Therefore, to test the generality of these findings, it is necessary to examine the hypotheses proposed in this paper using other countries with different characteristics. For instance, Anglo-Saxon countries such as the United States show a medium level of trust and low generosity from the welfare state, which is similar to Japan. However, the United States is regarded as a distinctly heterogeneous society. Hence, it is worthwhile testing the hypothesis of the present paper using data from the United States, and to then compare those results with the present paper. This is a remaining issue that can be addressed in future studies. 


\section{References}

Aghion, P., Algan, Y., Chahuc, P., \& Shleifer, A. (2010). Regulation and distrust. Quarterly Journal of Economics. 125(3), 1015-1049.

Alesina, A., \& Angeletos, G.M., (2005). Fairness and redistribution. American Economic Review, 95, 960-980.

Alesina, A., De Tella, R. \& MacCulloch, R. (2004). Inequality and happiness: are Europeans and Americans different? Journal of Public Economics, 88, 2009-2042.

Alesina, A., \& Giuliano, P., (2009). Preferences for redistribution. NBER Working Papers 14825.

Alesina, A., \& La Ferrara, E., (2005). Preferences for redistribution in the land of opportunities. Journal of Public Economics, 89, 897-931.

Algan, Y., \& Cahuc, P. (2009). Civic virtue and labor market institutions. American Economic Journal: macroeconomics, 1(1), 111-145.

Algan, Y., Cahuc, P \& Sangnier, M, (2011). Efficient and inefficient welfare states, IZA Discussion Paper 5445.

Bénabou, R. \& Ok, E. A. (2001). Social mobility and the demand for redistribution: The POUM hypothesis. Quarterly Journal of Economics, 116 (2), 447-487.

Bergh, A \& Bjørnskov, C (2011). Historical Trust Levels Predict the Current Size of the Welfare State. Kyklos, 64(1), 1-19.

Bjørnskov, C., Dreher,A, and Fischer, J.A.C.(2007). The bigger the better? Evidence of the effect of government size on life satisfaction around the world. Public Choice, 130, 267-292.

Bjørnskov, C., Dreher, A, and Fischer, J.A.V.. (2008a). Cross-country determinants of life satisfaction: exploring different determinants across groups in society. Social Choice and Welfare, 30, 119-173.

Bjørnskov, C., Dreher, A., and Fischer, J.A.V.. (2008b). „On decentralization and life satisfaction. Economics Letters, 99, 147-151.

Clark, A., \& Oswald, A., (1996). Satisfaction and comparison income. Journal of Public Economics, 61, 359-381.

Copeland, C., \& Laband, D.N., (2002). Expressiveness and voting. Public Choice, 110, 351-363.

Corneo, G., \& Grüner, H.P., (2002). Individual preferences for political distribution. Journal of Public Economics, 83, 83-107.

Cuccia, A. D \& Carnes, A. G. (2001), A closer look at the relation between tax 
complexity and tax equity perceptions. Journal of Economic Psychology, 22, 113-140.

Fehr, E. \& Schmidt, M. K. (1999). A theory of fairness, competition, and cooperation. Quarterly Journal of Economics , 114(3), 817-868.

Feld, L. P \& Frey, B. (2002), Trust breeds trust: how taxpayers are treated. Economic of Governance, 3, 87-99.

Feld, L. P \& Frey,B . (2007). Tax compliance as the result of a psychological tax contract: the role of incentives and responsive regulation. Law and Policy, 29, $102-120$.

Feld, L. P \& Larsen, C. (2012), Self-perceptions, government policies and tax compliance in Germany, International Tax Public Finance, 19, 78-103.

Galasso, V. (2003). Redistribution and fairness: A note. European Journal of Political Economy, 19, 885-892.

Gemmell, N., Oliver M \& Abuzer. P (2003). Tax perceptions and demand for public expenditure: evidence from UK micro-data. European Journal of Political Economy, 19, 793-816.

Gemmell, N., Oliver M \& Abuzer. P (2004). Tax perceptions and preferences over tax structure in the United Kingdom, Economic Journal, 114, F117-F138.

Gordon, J.P.F (1989). Individual morality and reputation cost as deterrents to tax evasion. European Economic Review, 33, 797-805.

Greene, W. (2008). Econometric Analysis (sixth ed.), Prentice-Hall, London.

Hammar, H., Jagers C, S. \& Nordblom, K. (2009). Perceived tax evasion and the importance of trust. Journal of Socio-economics, 38, 238-245.

Hillman, A.L. (2010), Expressive behavior in economics and politics. European Journal of Political Economy, 26, 403-418.

Klor, E.F., \& Shayo, M. (2010). Social identity and preferences over redistribution. Journal of Public Economics, 94, 269-278.

Kumlin, S. \& Rothstein, B. (2005). Making and breaking social capital: The impact of welfare state institution. Comparative Political Studies, 38(4), 339-365.

Luttmer, P. E (2005). Neighbors as negatives: Relative earnings and well-being. Quarterly Journal of Economics, 120 (3), 963-1002.

Luttmer, P. E \& Singhal, M. (2011). Culture, context, and the taste for redistribution. American Economic Journal: Economic Policy, 3 (1), 157-179.

Oh, H., \& Hong, J.H. (2012). Citizen's trust in government and their willingness to pay. Economics Letters, 115, 345-347.

Ohtake, F., \& Tomioka, J. (2004). Who supports redistribution? Japanese Economic 
Review, 55(4), 333-354.

Rainer, H. \& Siedler, T. (2008), Subjective income and employment expectations and preferences for redistribution. Economics Letters, 99, 449-453.

Ravallion, M. \& Lokshin, M. (2000). Who wants to redistribute? The tunnel effect in 1990 Russia. Journal of Public Economics, 76, 87-104.

Rothstein, B. \& Uslaner, E. (2006). All for all: equality, corruption and social trust. World Politics, 58, 41-72.

Scholz, J.T. \& Lubell, M. (1998). Trust and taxpaying: testing the heuristic approach to collective action. American Journal of Political Science, 42, 398-417.

Scholz, J.T. \& Pinney, N. (1995). Duty, fear, and tax compliance: the heuristic basis of citizenship behavior. American Journal of Political Science, 39, 490-512.

Sobel, R.S. \& Wagner, G.A. (2004), Expressive voting and government redistribution: testing Tullock's charity of the uncharitable. Public Choice, 119, 143-159.

Shields, M.A., Wheatley, PS. \& Wooden, M. (2009), Life satisfaction and economic and social characteristics of neighborhoods. Journal of Population Economics, $22,421-443$.

Torgler, B. (2003). Tax moral, rule governed behavior and trust. Constitutional Political Economy, 14, 119-140.

Tullock, G. (1971). The charity of the uncharitable. Western Economic Journal, 9, 379-392.

Wenzel, M (2004). An analysis of norm processes in tax compliance. Journal of Economic Psychology, 25, 213-228.

Wenzel, M (2005 a). Motivation or rationalization? Causal relations between ethics, norms and tax compliance. Journal of Economic Psychology, 26, 491-508.

Wenzel, M (2005 b). Misperception of social norms about tax compliance: from theory to intervention. Journal of Economic Psychology, 26, 862-883.

Yamamura, E. (2012a). Government size and trust. Review of Social Economy, 70(1), $31-56$.

Yamamura, E. (2012b). Social capital, household income, and preferences for income redistribution. Forthcoming in European Journal of Political Economy. 


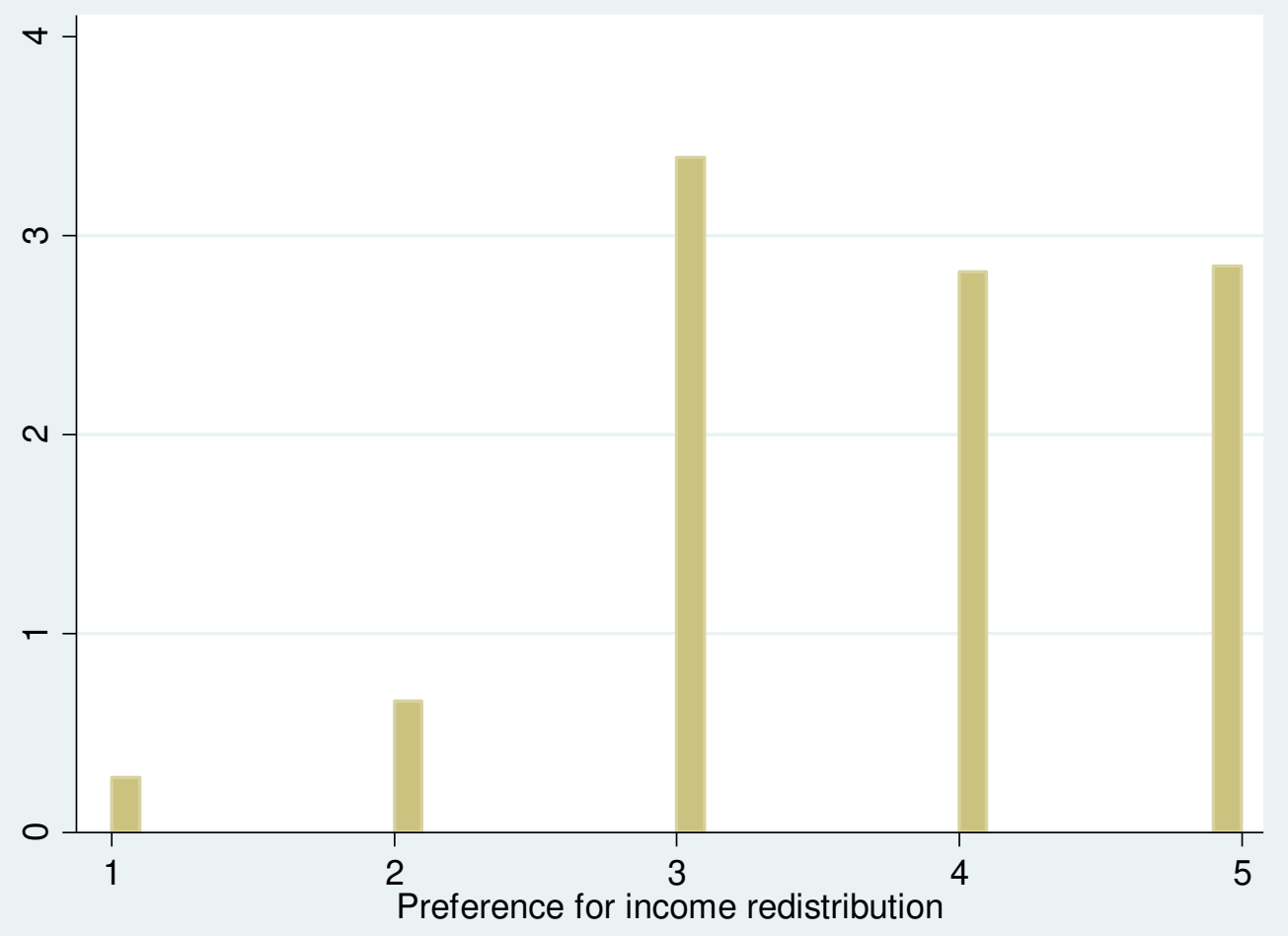

Figure 1. Distribution of preference for income redistribution 


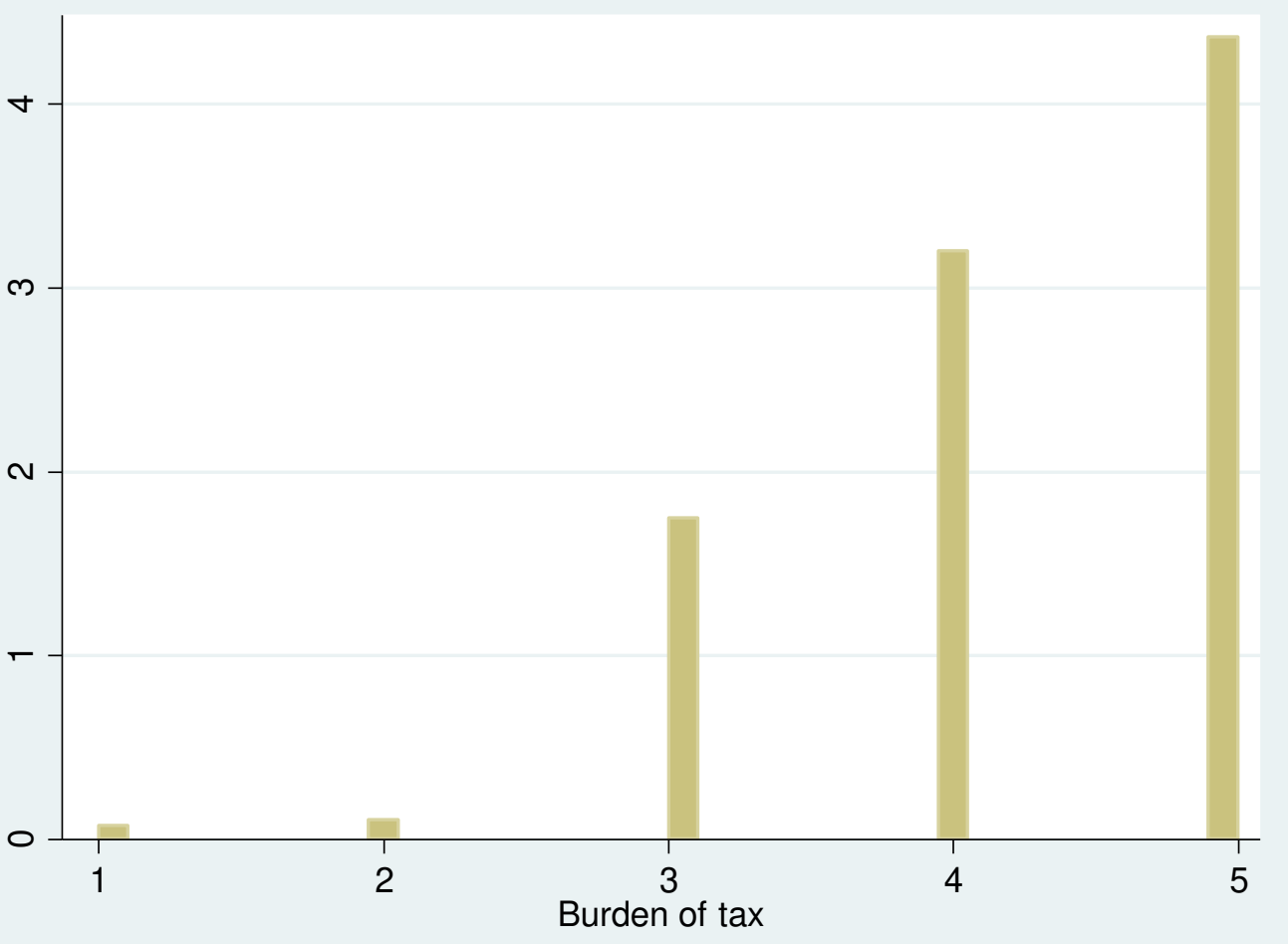

Figure 2. Distribution of perceived tax burden 


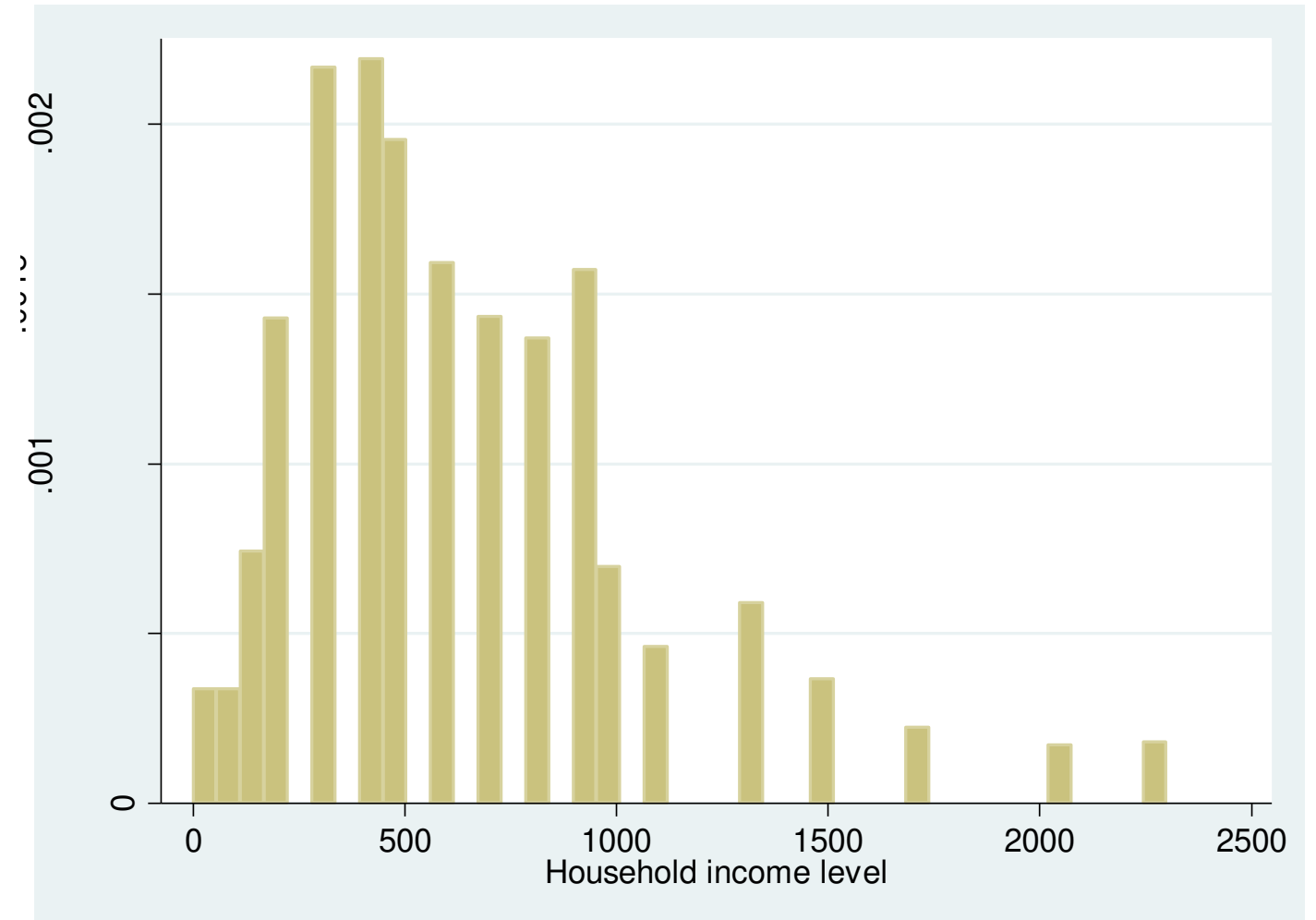

Figure 3. Distribution of household income 


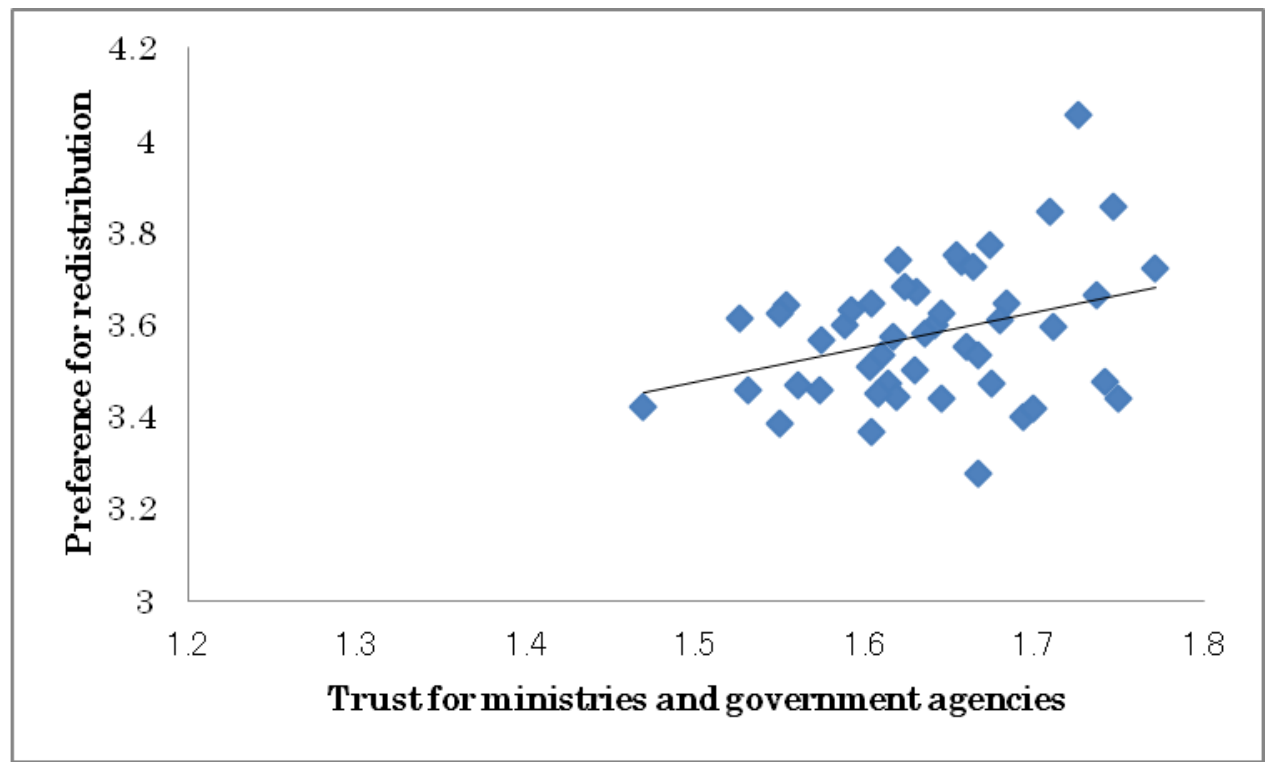

Figure 4(a). Relationship between preference for income distribution and trust for ministries and government agencies (high-income group)

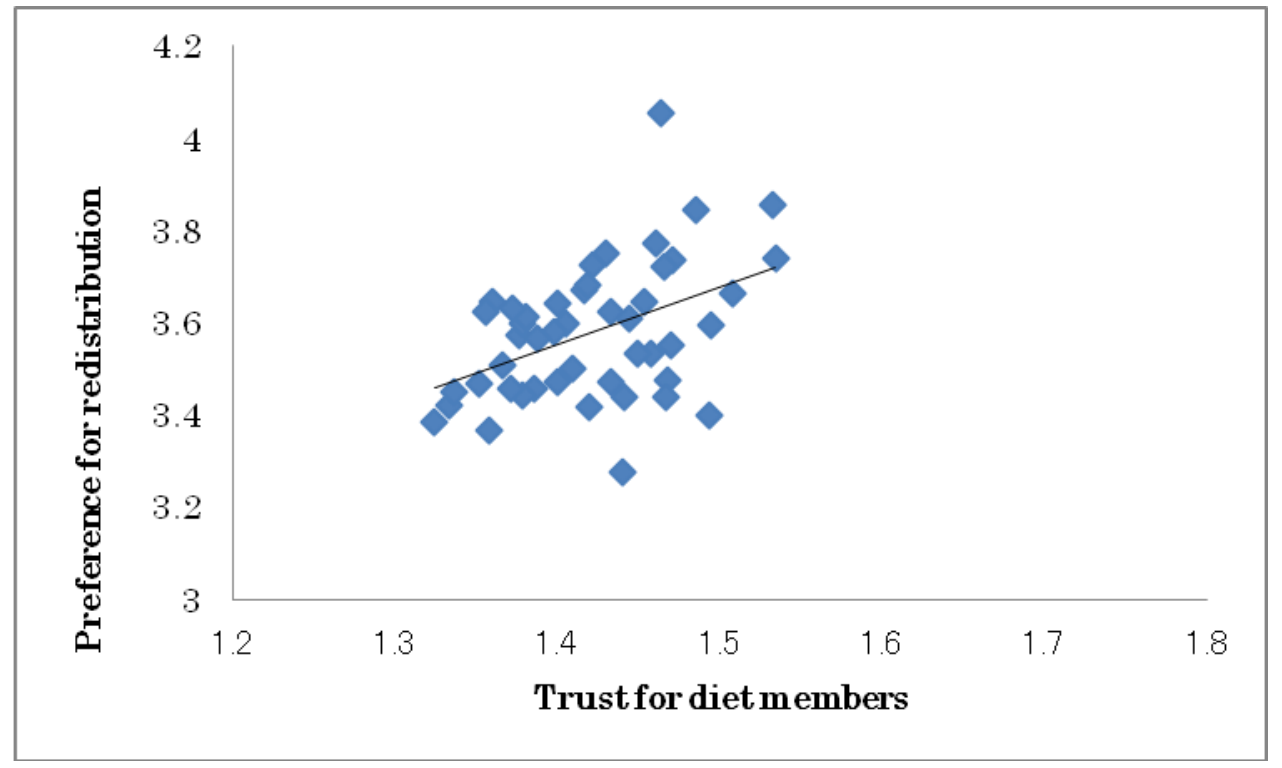

Figure 4(b). Relationship between preference for income distribution and trust for diet members (high-income group) 


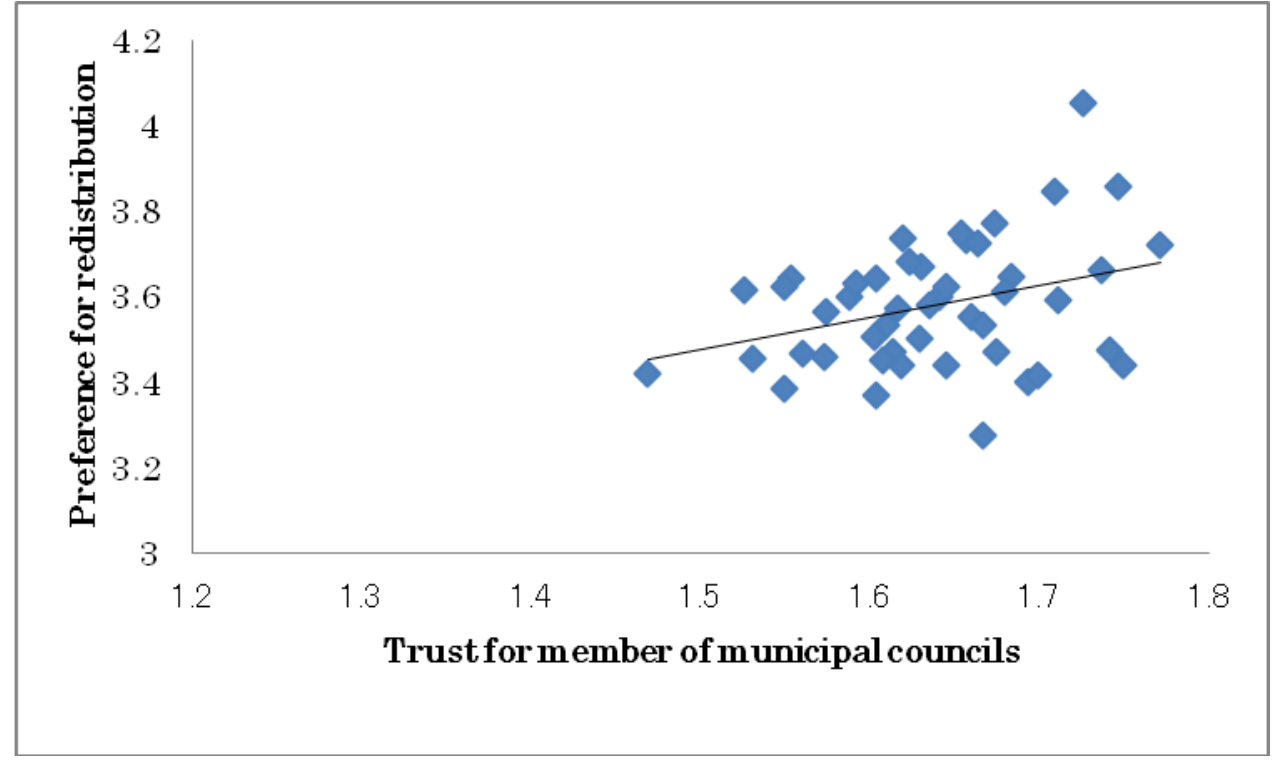

Figure 4(c). Relationship between preference for income distribution and trust for members of municipal councils (high-income group) 


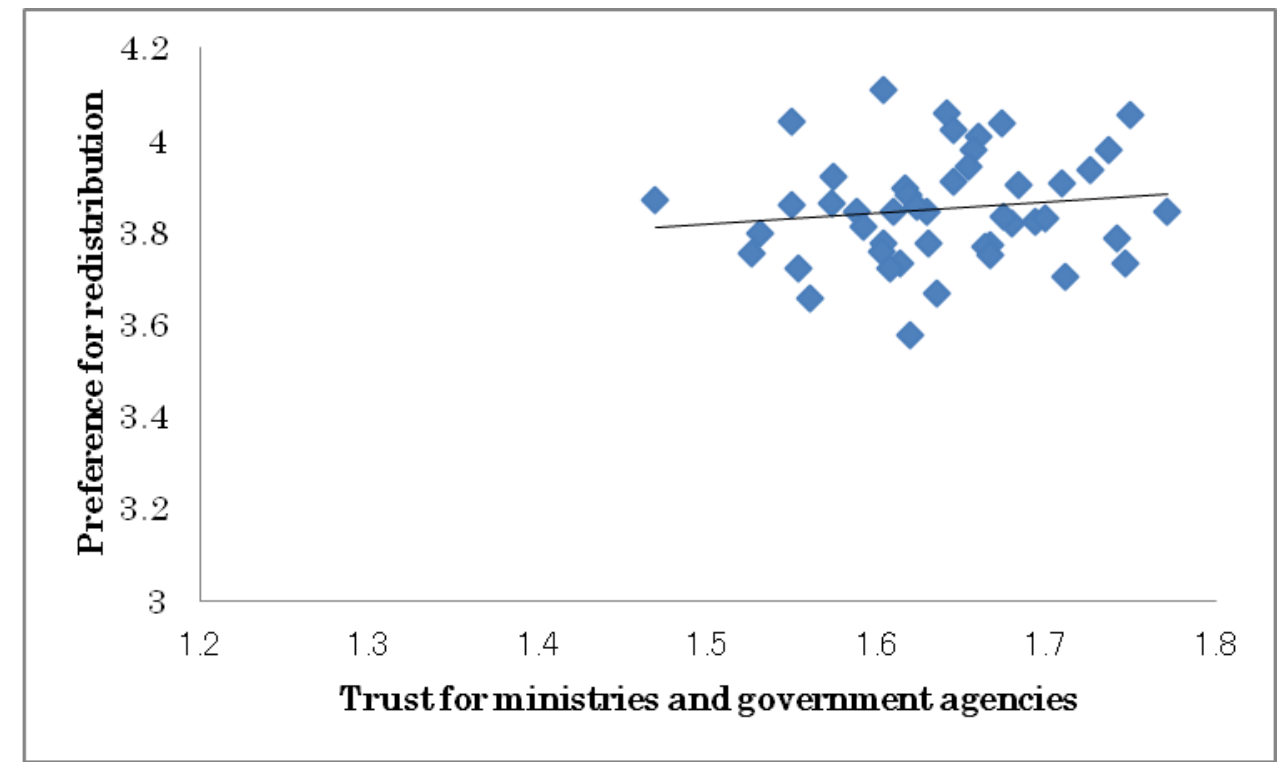

Figure 5(a). Relationship between preference for income distribution and trust for ministries and government agencies (low-income group)

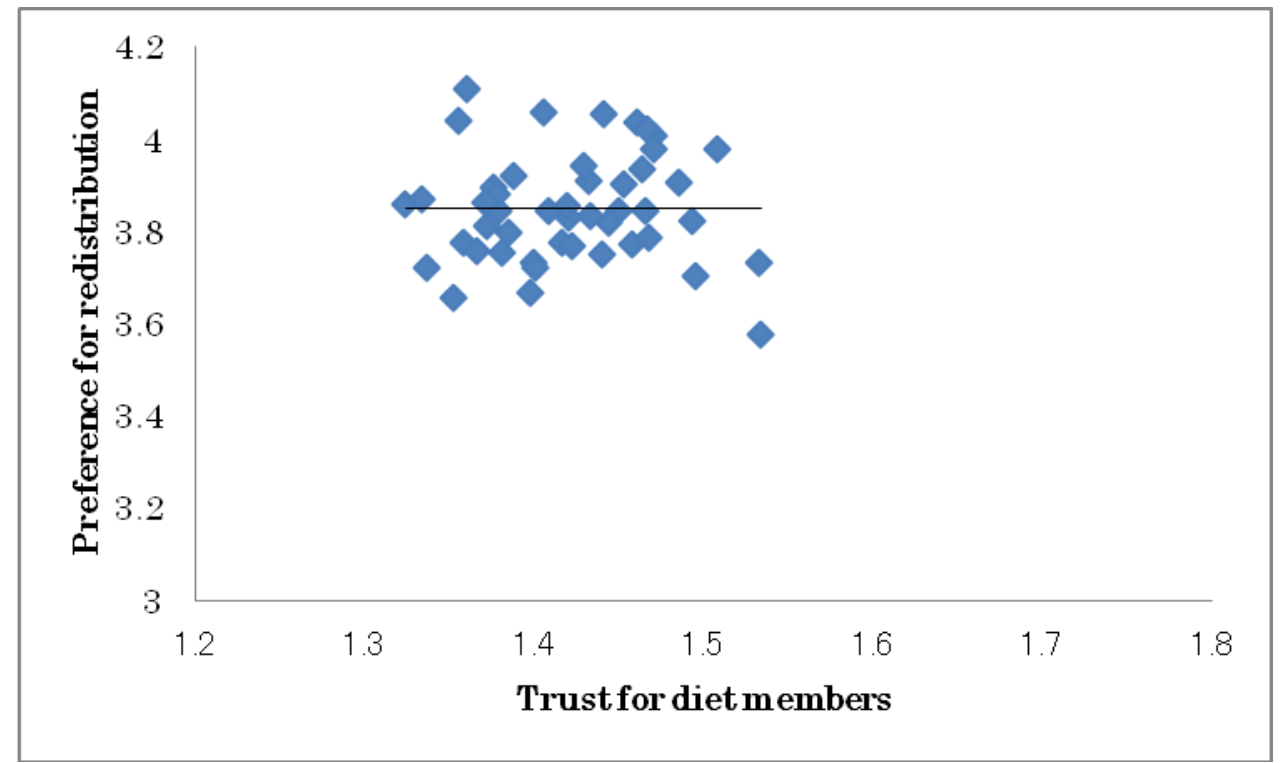

Figure 5(b). Relationship between preference for income distribution and trust for diet members (low-income group) 


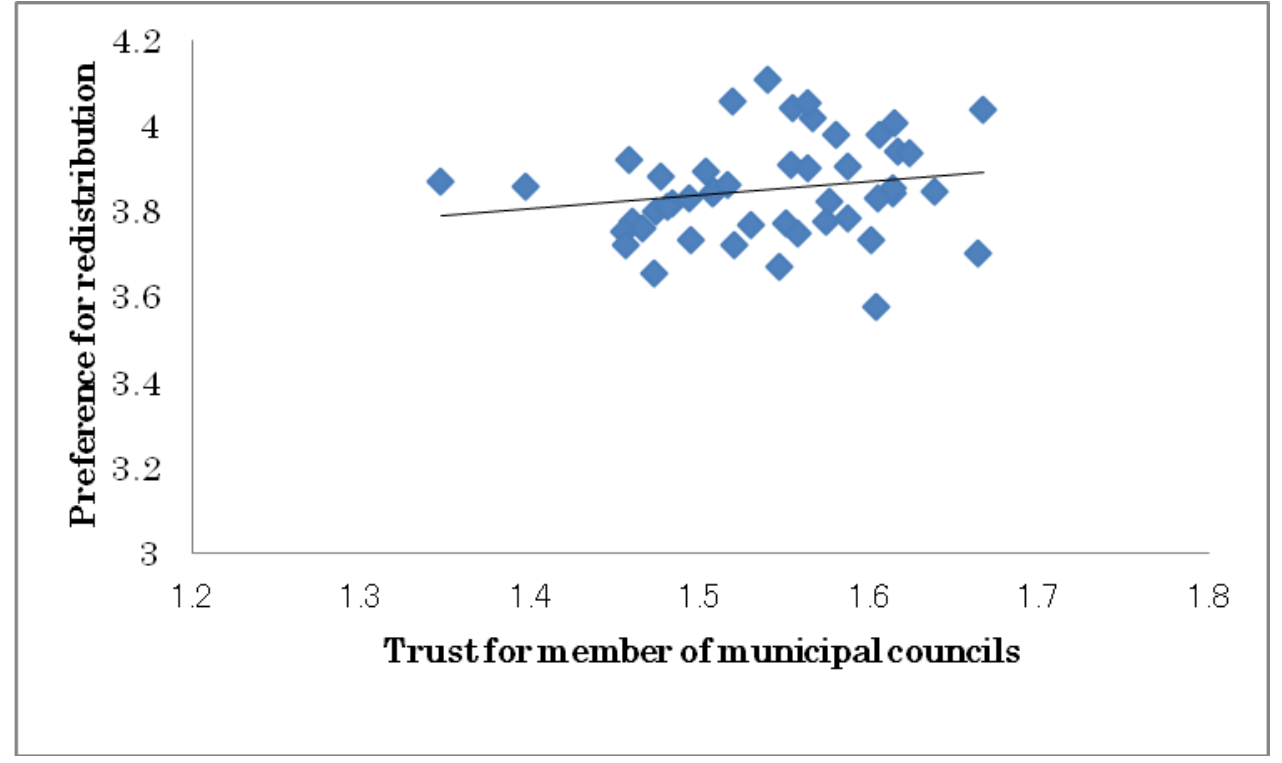

Figure 5(c). Relationship between preference for income distribution and trust for members of municipal councils (low-income group) 


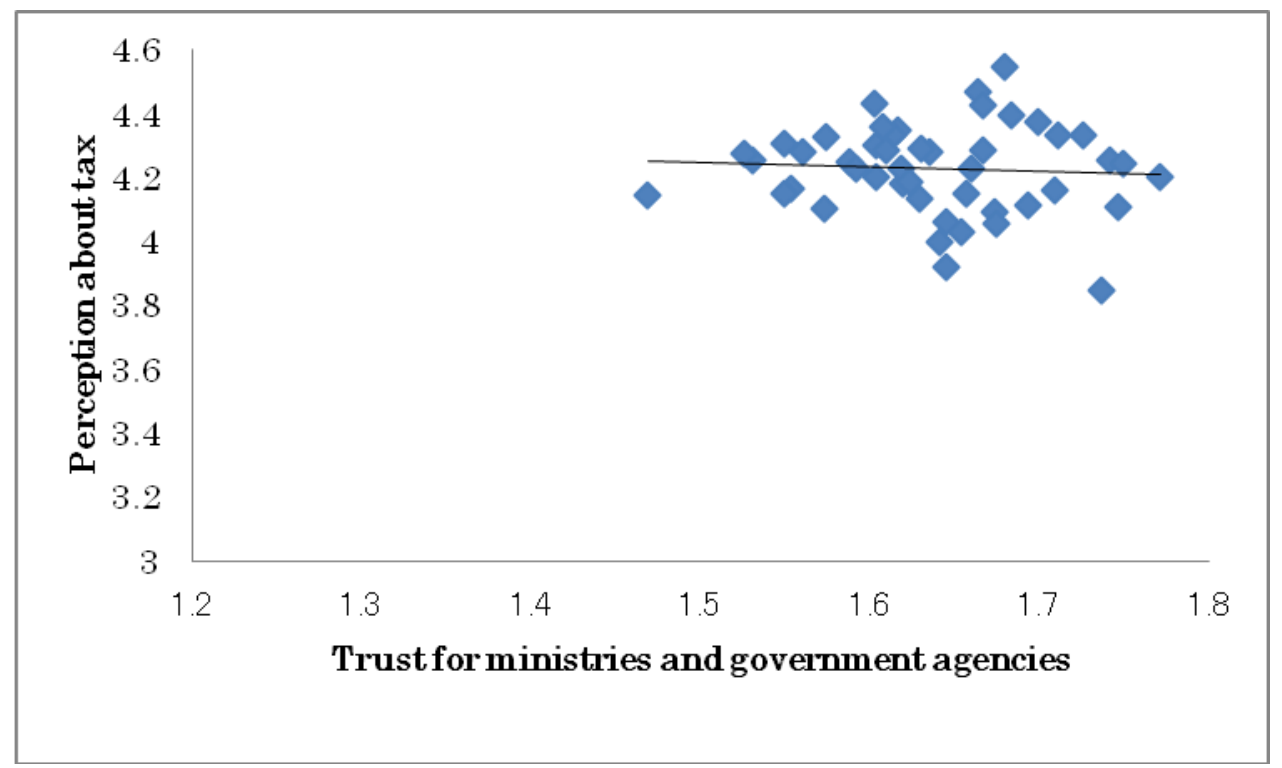

Figure 6(a). Relationship between perceptions regarding tax and trust for ministries and government agencies (high-income group)

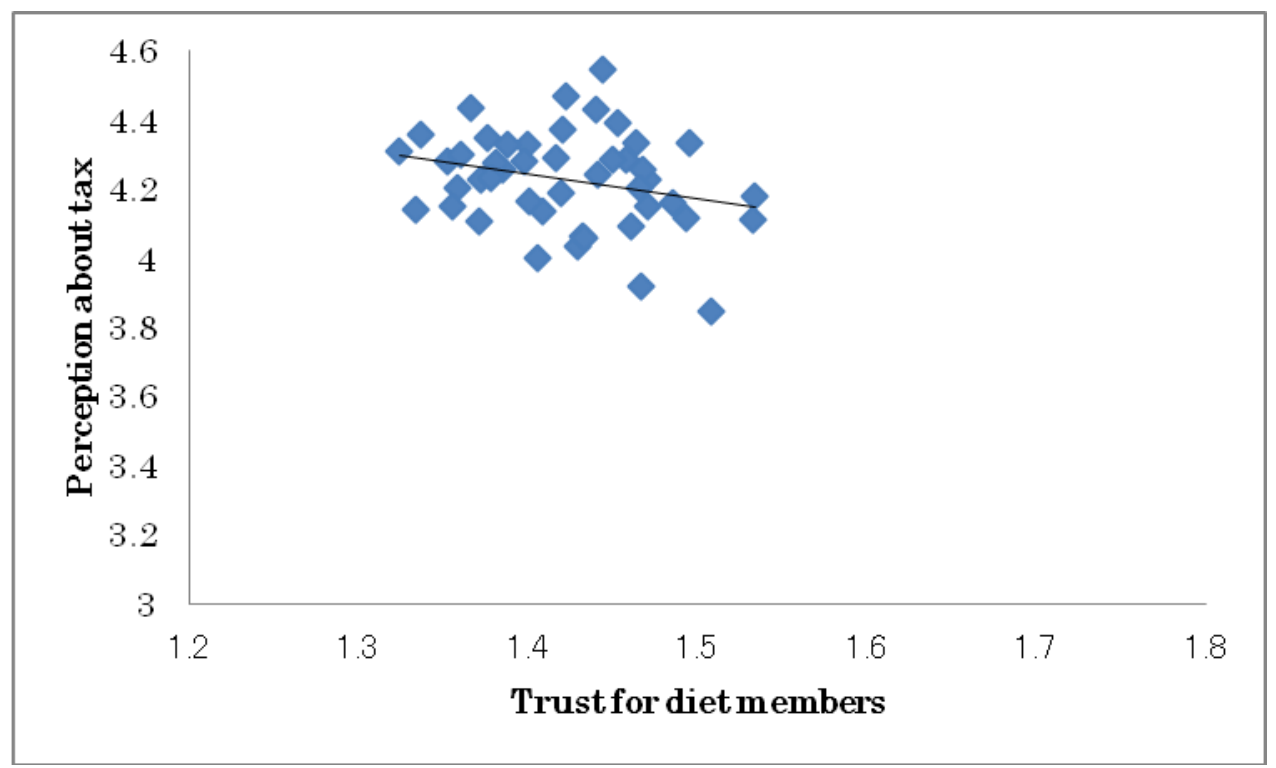

Figure 6(b). Relationship between perceptions regarding tax and trust for diet members (high-income group) 


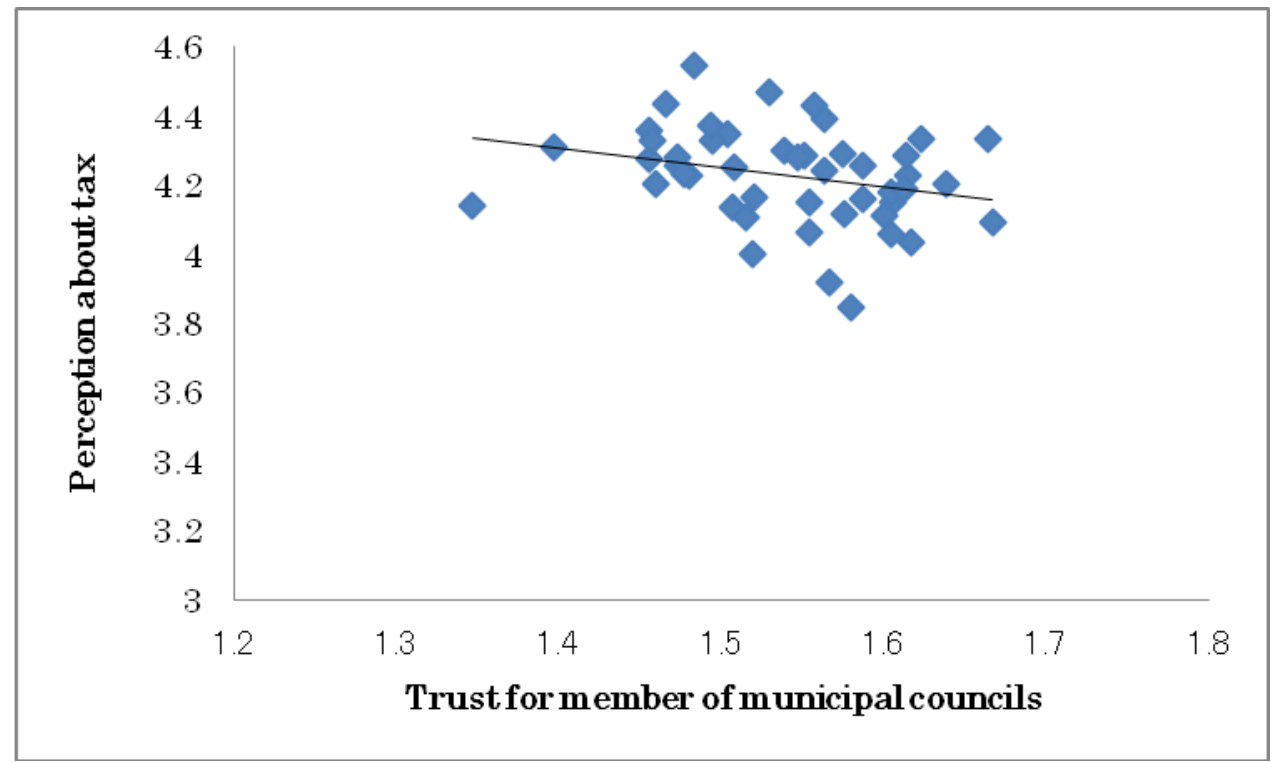

Figure 6(c). Relationship between perceptions regarding tax and trust for members of municipal councils (high-income group) 


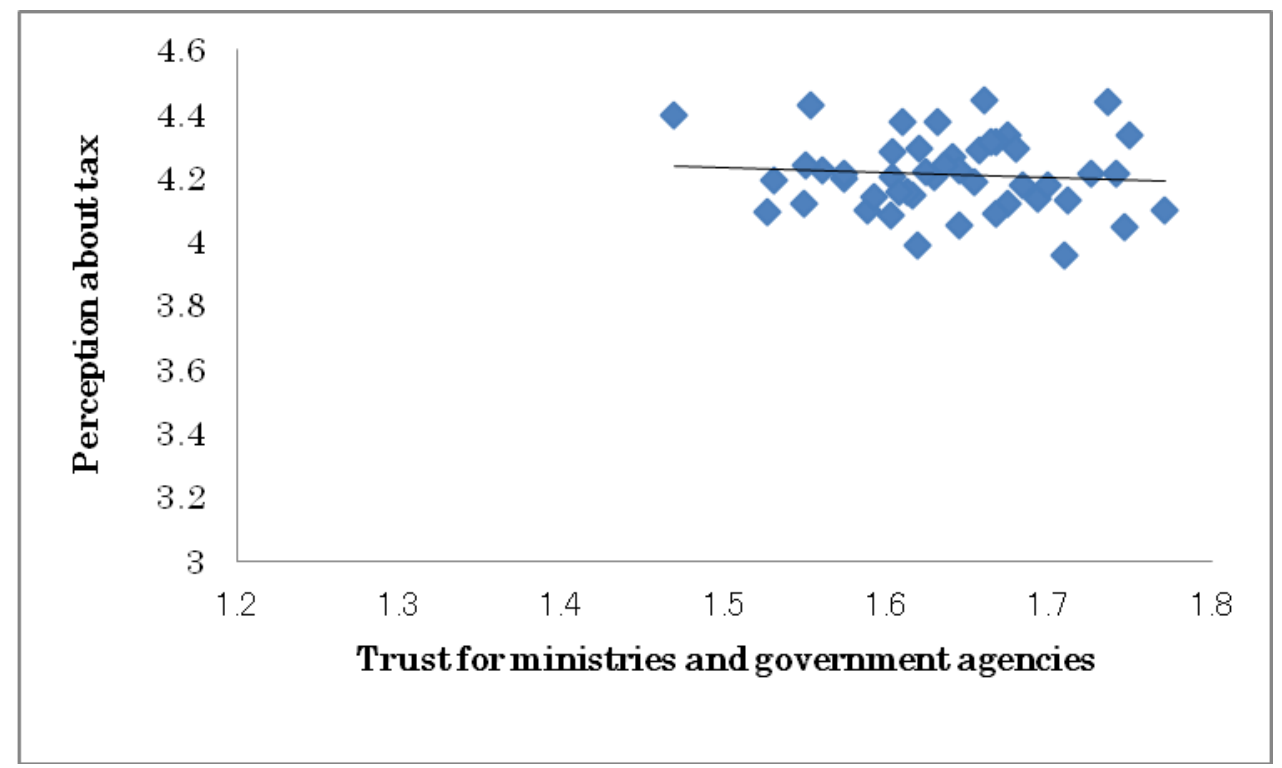

Figure 7(a). Relationship between perceptions regarding tax and trust for ministries and government agencies (low-income group)

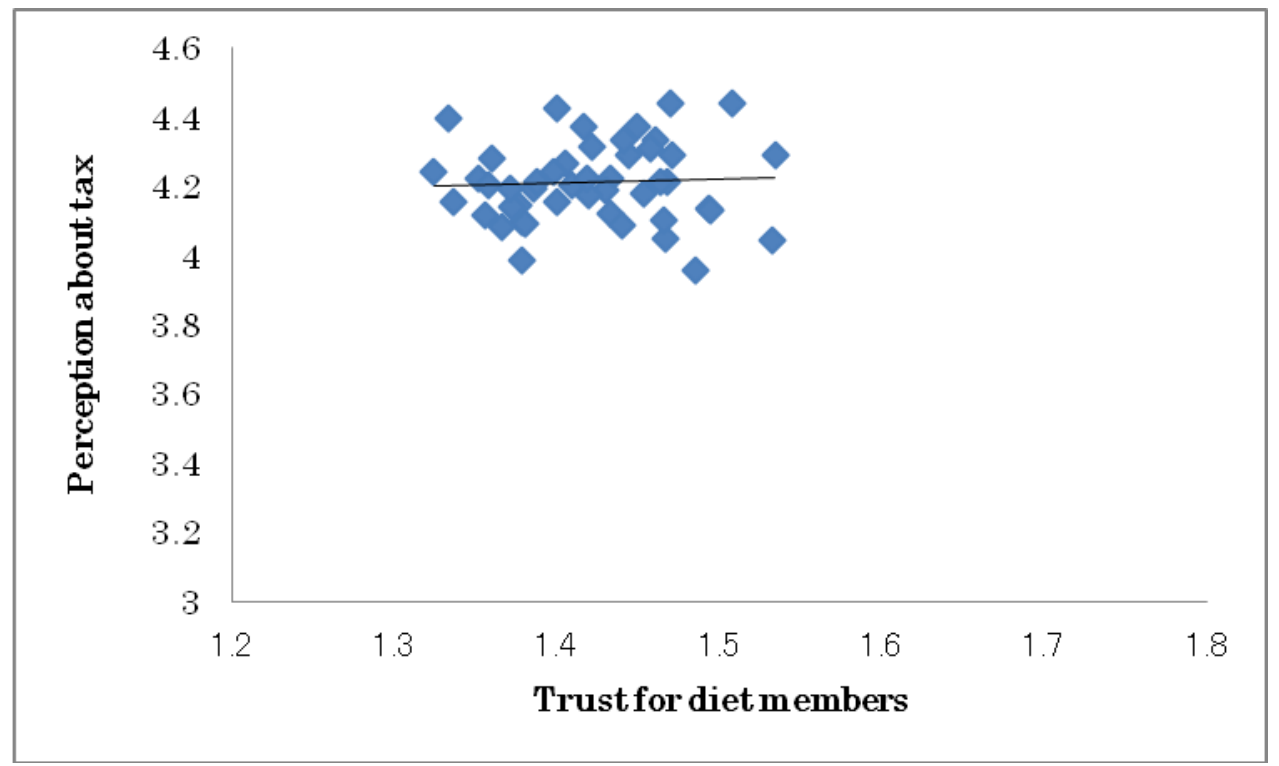

Figure 7(b). Relationship between perceptions regarding tax and trust for diet members (low-income group) 


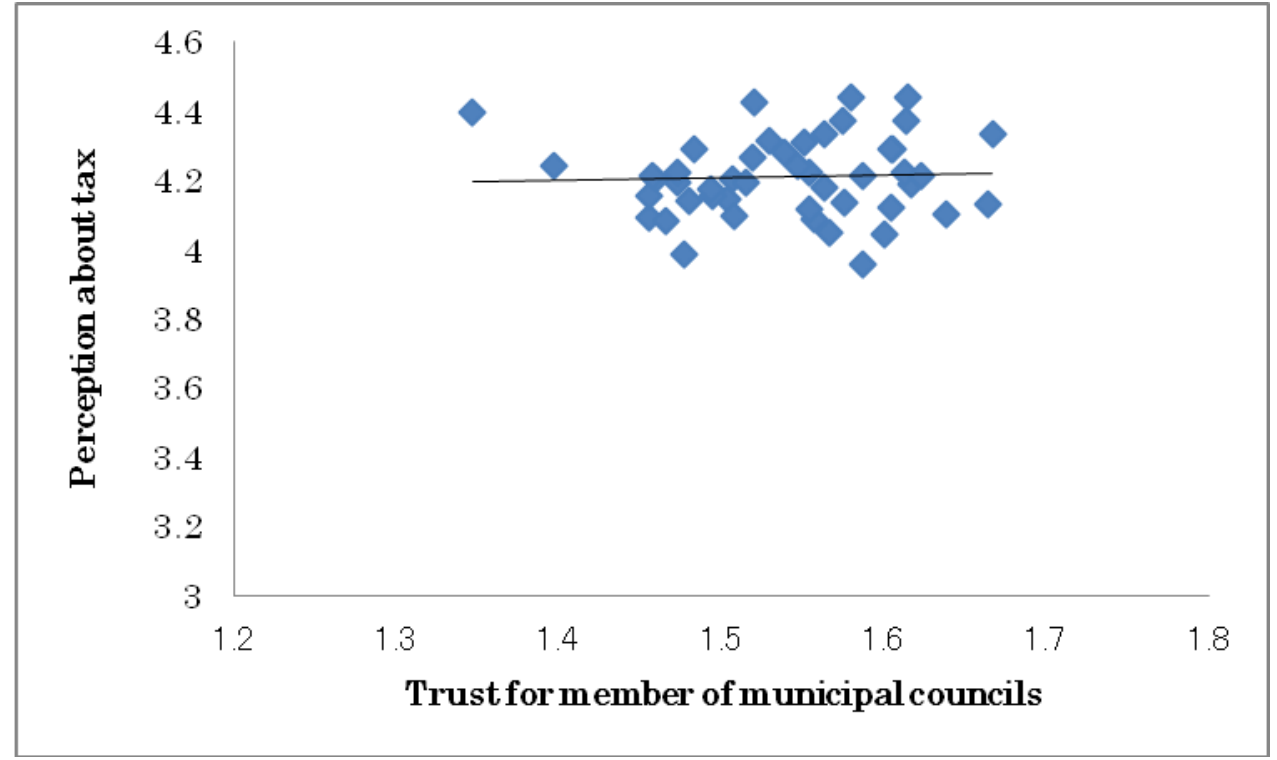

Figure 7(c). Relationship between perceptions regarding tax and trust for members of municipal councils (low-income group) 
Table 1

Definitions and basic statistics

\begin{tabular}{|c|c|c|c|c|c|}
\hline & Definitions & Mean & $\begin{array}{l}\text { Standard } \\
\text { deviation }\end{array}$ & Maximum & Minimum \\
\hline \multicolumn{6}{|l|}{$\begin{array}{l}\text { Regional } \\
\text { characteristics }\end{array}$} \\
\hline $\begin{array}{l}\text { TRUST } \\
\text { MINIS }\end{array}$ & $\begin{array}{l}\text { Degree of trust for ministries and government } \\
\text { agencies: } 1 \text { (not very much) }-3 \text { (very much). } \\
\text { Average values within prefecture where } \\
\text { respondents reside. }\end{array}$ & 1.61 & 0.05 & 1.77 & 1.46 \\
\hline $\begin{array}{l}\text { TRUST }_{-} \\
\text {DIET }\end{array}$ & $\begin{array}{l}\text { Degree of trust for diet members: } 1 \text { (not very } \\
\text { much) }-3 \text { (very much). } \\
\text { Average values within prefecture where } \\
\text { respondents reside. }\end{array}$ & 1.40 & 0.04 & 1.53 & 1.32 \\
\hline $\begin{array}{l}\text { TRUST_ } \\
\text { MUNI }\end{array}$ & $\begin{array}{l}\text { Degree of trust for members of municipal } \\
\text { councils: } 1 \text { (not very much) }-3 \text { (very much). } \\
\text { Average values within prefecture where } \\
\text { respondents reside. }\end{array}$ & 1.51 & 0.06 & 1.66 & 1.34 \\
\hline AVINCOM & $\begin{array}{l}\text { Average household income within a prefecture } \\
\text { (million yen) }\end{array}$ & 6.12 & 0.83 & 7.99 & 3.52 \\
\hline GINI & Gini coefficients for 1999 & 0.29 & 0.01 & 0.35 & 0.27 \\
\hline \multicolumn{6}{|l|}{$\begin{array}{l}\text { Individual } \\
\text { characteristics }\end{array}$} \\
\hline EQUAL & $\begin{array}{l}\text { Degree of agreement with the argument that the } \\
\text { government should reduce income inequality: } \\
1 \text { (strongly disagree) }-5 \text { (strongly agree) }\end{array}$ & 3.72 & 1.03 & 5 & 1 \\
\hline TAX & $\begin{array}{l}\text { Degree of perceived tax burden: } \\
1 \text { (too low) }-5 \text { (too high) }\end{array}$ & 4.22 & 0.84 & 5 & 1 \\
\hline INCOM & $\begin{array}{l}\text { Individual household income } \\
\text { (million yen) }\end{array}$ & 6.23 & 4.18 & 23 & 0 \\
\hline AGE & Ages & 53.5 & 15.2 & 89 & 20 \\
\hline MARRY & $\begin{array}{l}\text { Takes } 1 \text { if respondents are currently married, } \\
\text { otherwise } 0 .\end{array}$ & 0.82 & - & 1 & 0 \\
\hline SCHOOL & Years of schooling & 12.2 & 2.55 & 18 & 6 \\
\hline UNEMP & $\begin{array}{l}\text { Takes } 1 \text { if respondents are currently unemployed, } \\
\text { otherwise } 0 .\end{array}$ & 0.01 & 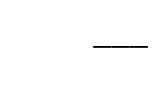 & 1 & 0 \\
\hline MALE & Takes 1 if respondents are male, otherwise 0 . & 0.49 & - & 1 & 0 \\
\hline PROG_1 & $\begin{array}{l}\text { Concerning political views, it takes } 1 \text { if } \\
\text { respondents choose } 1 \text {, otherwise } 0 \text {. } \\
1 \text { (conservative) }-5 \text { (progressive) }\end{array}$ & 0.08 & 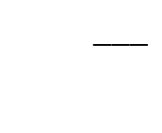 & 1 & 0 \\
\hline PROG_2 & $\begin{array}{l}\text { Concerning political views, it takes } 1 \text { if } \\
\text { respondents choose } 2 \text {, otherwise } 0 \text {. } \\
1 \text { (conservative) }-5 \text { (progressive) }\end{array}$ & 0.20 & 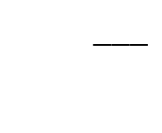 & 1 & 0 \\
\hline PROG_3 & $\begin{array}{l}\text { Concerning political views, it takes } 1 \text { if } \\
\text { respondents choose } 3 \text {, otherwise } 0\end{array}$ & 0.50 & 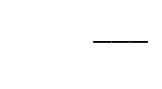 & 1 & 0 \\
\hline
\end{tabular}


1 (conservative) -5 (progressive)

$\begin{array}{lllll}\text { PROG_4 } & \begin{array}{l}\text { Concerning political views, it takes } 1 \text { if } \\ \text { respondents choose } 4, \text { otherwise } 0 .\end{array} & 0.18 & & 0 \\ & 1 \text { (conservative) }-5 \text { (progressive) } \\ \text { PROG_5 } & \begin{array}{l}\text { Concerning political views, it takes } 1 \text { if } \\ \text { respondents choose } 5 \text {, otherwise } 0 .\end{array} \\ & 1 \text { (conservative) }-5 \text { (progressive) }\end{array}$

Note: All observations are used. Absolute values of t-statistics are the results of a mean difference test between high- and low-income household groups. $*, * *$, and $* * *$ indicate significance at the $10 \%, 5 \%$, and $1 \%$ levels, respectively. 
Table 2

Comparison of key variables between "high-income group" and "low-income group"

\begin{tabular}{lrrl}
\hline & High income & Low income & t-statistics \\
\hline EQUAL & 3.54 & 3.85 & $15.6^{* * *}$ \\
TAX & 4.25 & 4.20 & $2.54^{* *}$ \\
TRUST_MINIS & 1.61 & 1.62 & $6.29^{* * *}$ \\
TRUST_DIET & 1.40 & 1.40 & 0.58 \\
TRUST_MUNI & 1.51 & 1.52 & $2.82^{* * *}$
\end{tabular}

Note: Respondents whose annual household income higher than 6 million yen. Respondents whose annual household income (or equivalent to) lower than 6 million yen. All observations are used. Absolute values of t-statistics are the results of a mean difference test between high- and low-income household groups. *** indicates significance at the $1 \%$ level. 
Table 3

Correlation matrix for main variables used for baseline model.

\begin{tabular}{|c|c|c|c|c|c|c|c|c|c|c|c|c|c|}
\hline & EQUAL & TAX & $\begin{array}{l}\text { TRUST }_{-} \\
\text {MINIS }\end{array}$ & $\begin{array}{l}\text { TRUST }_{-} \\
\text {DIET }\end{array}$ & $\begin{array}{l}\text { TRUST }_{-} \\
\text {MUNI }\end{array}$ & AVINCOM & GINI & INCOM & AGE & MARRY & $\begin{array}{l}\mathrm{SCHOO} \\
\mathrm{L}\end{array}$ & UNEMP & MALE \\
\hline EQUAL & 1.00 & & & & & & & & & & & & \\
\hline TAX & $\begin{array}{l}0.04^{* * * *} \\
(0.00)\end{array}$ & 1.00 & & & & & & & & & & & \\
\hline TRUST_MINIS & $\begin{array}{l}0.04^{* * * *} \\
(0.00)\end{array}$ & $\begin{array}{l}-0.01^{*} \\
(0.09)\end{array}$ & 1.00 & & & & & & & & & & \\
\hline TRUST_DIET & $\begin{array}{l}0.03^{* * *} \\
(0.00)\end{array}$ & $\begin{array}{l}-0.01 \\
(0.14)\end{array}$ & $\begin{array}{l}0.76^{* * *} \\
(0.00)\end{array}$ & 1.00 & & & & & & & & & \\
\hline TRUST_MUNI & $\begin{array}{l}0.04^{* * * *} \\
(0.00)\end{array}$ & $\begin{array}{l}-0.01 \\
(0.17)\end{array}$ & $\begin{array}{l}0.72^{* * * *} \\
(0.00)\end{array}$ & $\begin{array}{l}0.83^{* * *} \\
(0.00)\end{array}$ & 1.00 & & & & & & & & \\
\hline AVINCOM & $\begin{array}{l}-0.06^{* * *} \\
(0.00)\end{array}$ & $\begin{array}{l}0.0001 \\
(0.93)\end{array}$ & $\begin{array}{l}-0.33^{* * * *} \\
(0.00)\end{array}$ & $\begin{array}{l}-0.07^{* * * *} \\
(0.00)\end{array}$ & $\begin{array}{l}-0.02^{* * * *} \\
(0.00)\end{array}$ & 1.00 & & & & & & & \\
\hline GINI & $\begin{array}{l}-0.003 \\
(0.69)\end{array}$ & $\begin{array}{l}-0.005 \\
(0.64)\end{array}$ & $\begin{array}{l}-0.05^{* * * *} \\
(0.00)\end{array}$ & $\begin{array}{l}-0.19^{* * * *} \\
(0.00)\end{array}$ & $\begin{array}{l}-0.14^{* * * *} \\
(0.00)\end{array}$ & $\begin{array}{l}-0.10^{* * * *} \\
(0.00)\end{array}$ & 1.00 & & & & & & \\
\hline INCOM & $\begin{array}{l}-0.15^{* * *} \\
(0.00)\end{array}$ & $\begin{array}{l}0.04^{* * * *} \\
(0.00)\end{array}$ & $\begin{array}{l}-0.07 * * * \\
(0.00)\end{array}$ & $\begin{array}{l}-0.02^{* *} \\
(0.01)\end{array}$ & $\begin{array}{l}-0.04^{* * * *} \\
(0.00)\end{array}$ & $\begin{array}{l}0.20^{* * * *} \\
(0.00)\end{array}$ & $\begin{array}{l}-0.01 \\
(0.14)\end{array}$ & 1.00 & & & & & \\
\hline AGE & $\begin{array}{l}0.11^{* * * *} \\
(0.00)\end{array}$ & $\begin{array}{l}-0.06^{* * *} \\
(0.00)\end{array}$ & $\begin{array}{l}0.02^{* *} \\
(0.02)\end{array}$ & $\begin{array}{l}0.01^{*} \\
(0.06)\end{array}$ & $\begin{array}{l}0.01^{* *} \\
(0.02)\end{array}$ & $\begin{array}{l}-0.04^{* * * *} \\
(0.00)\end{array}$ & $\begin{array}{l}-0.01^{*} \\
(0.06)\end{array}$ & $\begin{array}{l}-0.19 * * * \\
(0.00)\end{array}$ & 1.00 & & & & \\
\hline MARRY & $\begin{array}{l}-0.007 \\
(0.44)\end{array}$ & $\begin{array}{l}0.01 \\
(0.18)\end{array}$ & $\begin{array}{l}0.004 \\
(0.59)\end{array}$ & $\begin{array}{l}0.02^{* *} \\
(0.01)\end{array}$ & $\begin{array}{l}0.01 \\
(0.14)\end{array}$ & $\begin{array}{l}0.04^{* * * *} \\
(0.00)\end{array}$ & $\begin{array}{l}-0.01^{*} \\
(0.05)\end{array}$ & $\begin{array}{l}0.23^{* * * *} \\
(0.00)\end{array}$ & $\begin{array}{l}-0.02^{* * *} \\
(0.00)\end{array}$ & 1.00 & & & \\
\hline UNEMP & $\begin{array}{l}0.01^{*} \\
(0.05)\end{array}$ & $\begin{array}{l}0.003 \\
(0.78)\end{array}$ & $\begin{array}{l}-0.001 \\
(0.94)\end{array}$ & $\begin{array}{l}-0.005 \\
(0.54)\end{array}$ & $\begin{array}{l}-0.003 \\
(0.67)\end{array}$ & $\begin{array}{l}-0.03^{* * * *} \\
(0.00)\end{array}$ & $\begin{array}{l}0.04^{* * * *} \\
(0.00)\end{array}$ & $\begin{array}{l}-0.05^{* * *} \\
(0.00)\end{array}$ & $\begin{array}{l}-0.03^{* * *} \\
(0.00)\end{array}$ & $\begin{array}{l}-0.06^{* * * *} \\
(0.00)\end{array}$ & $\begin{array}{l}-0.01 \\
(0.28)\end{array}$ & 1.00 & \\
\hline MALE & $\begin{array}{l}0.02^{* * *} \\
(0.00)\end{array}$ & $\begin{array}{l}-0.003 \\
(0.76)\end{array}$ & $\begin{array}{l}0.004 \\
(0.59)\end{array}$ & $\begin{array}{l}0.01^{* * *} \\
(0.02)\end{array}$ & $\begin{array}{l}0.01 \\
(0.35)\end{array}$ & $\begin{array}{l}0.01 \\
(0.22)\end{array}$ & $\begin{array}{l}-0.02^{* *} \\
(0.01)\end{array}$ & $\begin{array}{l}0.04^{* * *} \\
(0.00)\end{array}$ & $\begin{array}{l}0.04^{* * * *} \\
(0.00)\end{array}$ & $\begin{array}{l}0.11^{* * *} \\
(0.00)\end{array}$ & $\begin{array}{l}0.10^{* * * *} \\
(0.00)\end{array}$ & $\begin{array}{l}0.03^{* * * *} \\
(0.00)\end{array}$ & 1.00 \\
\hline
\end{tabular}

Numbers in parentheses are $p$-statistics. ${ }^{*}, * *$, and $* * *$ indicate significance at the $10 \%, 5 \%$ and $1 \%$ levels, respectively. 
Table 4 Baseline model: dependent variable is EQUAL (ordered probit model)

\begin{tabular}{|c|c|c|c|c|c|c|c|c|c|}
\hline & $\begin{array}{l}(1) \\
\text { All }\end{array}$ & $\begin{array}{c}(2) \\
\text { High income }\end{array}$ & $\begin{array}{c}\text { (3) } \\
\text { Low income }\end{array}$ & $\begin{array}{l}(4) \\
\text { All }\end{array}$ & $\begin{array}{c}(5) \\
\text { High income }\end{array}$ & $\begin{array}{c}(6) \\
\text { Low income }\end{array}$ & $\begin{array}{l}\text { (7) } \\
\text { All }\end{array}$ & $\begin{array}{l}\quad(8) \\
\text { High } \\
\text { income }\end{array}$ & $\begin{array}{c}(9) \\
\text { Low income }\end{array}$ \\
\hline \multicolumn{10}{|l|}{$\begin{array}{l}\text { Regional } \\
\text { characteristics }\end{array}$} \\
\hline TRUST_MINIS & $\begin{array}{l}0.31^{*} \\
(1.81)\end{array}$ & $\begin{array}{l}0.64 * * * \\
(2.59)\end{array}$ & $\begin{array}{l}0.12 \\
(0.59)\end{array}$ & & & & & & \\
\hline TRUST_DIET & & & & $\begin{array}{l}0.48 * * \\
(2.46)\end{array}$ & $\begin{array}{l}1.17 * * * \\
(4.00)\end{array}$ & $\begin{array}{l}0.10 \\
(0.33)\end{array}$ & & & \\
\hline TRUST_MUNI & & & & & & & $\begin{array}{l}0.44 * * * \\
(3.72)\end{array}$ & $\begin{array}{l}0.92 * * * \\
(4.87)\end{array}$ & $\begin{array}{l}0.18 \\
(1.02)\end{array}$ \\
\hline AVINCOM & $\begin{array}{l}-0.03 * * * \\
(-2.81)\end{array}$ & $\begin{array}{l}-0.01 \\
(-0.42)\end{array}$ & $\begin{array}{r}-0.05 * * * \\
(-3.21)\end{array}$ & $\begin{array}{l}-0.03 * * * \\
(-3.57)\end{array}$ & $\begin{array}{l}-0.01 \\
(-1.47)\end{array}$ & $\begin{array}{r}-0.05 * * * \\
(-3.49)\end{array}$ & $\begin{array}{l}-0.03 * * * \\
(-3.02)\end{array}$ & $\begin{array}{l}-0.01 \\
(-0.58)\end{array}$ & $\begin{array}{c}-0.05 * * * \\
(-3.28)\end{array}$ \\
\hline GINI & $\begin{array}{c}-0.43 \\
(-0.51)\end{array}$ & $\begin{array}{l}2.07 * * \\
(1.98)\end{array}$ & $\begin{array}{l}-1.84 \\
(-1.52)\end{array}$ & $\begin{array}{c}-0.21 \\
(-0.26)\end{array}$ & $\begin{array}{l}2.97 * * * \\
(3.08)\end{array}$ & $\begin{array}{l}-1.82 \\
(-1.51)\end{array}$ & $\begin{array}{c}-0.21 \\
(-0.25)\end{array}$ & $\begin{array}{l}2.73 * * * \\
(2.96)\end{array}$ & $\begin{array}{l}-1.76 \\
(-1.48)\end{array}$ \\
\hline \multicolumn{10}{|l|}{$\begin{array}{l}\text { Individual } \\
\text { characteristics }\end{array}$} \\
\hline INCOM & $\begin{array}{l}-0.03 * * * \\
(-10.6)\end{array}$ & $\begin{array}{l}-0.02 * * * \\
(-5.38)\end{array}$ & $\begin{array}{l}-0.01 \\
(-0.99)\end{array}$ & $\begin{array}{l}-0.03^{* * *} \\
(-10.6)\end{array}$ & $\begin{array}{l}-0.02^{* * * *} \\
(-5.33)\end{array}$ & $\begin{array}{l}-0.01 \\
(-0.99)\end{array}$ & $\begin{array}{l}-0.03 * * * \\
(-10.6)\end{array}$ & $\begin{array}{l}-0.02^{* * * *} \\
(-5.35)\end{array}$ & $\begin{array}{l}-0.01 \\
(-0.99)\end{array}$ \\
\hline AGE & $\begin{array}{l}0.004 * * * \\
(6.82)\end{array}$ & $\begin{array}{l}0.007 * * * \\
(5.24)\end{array}$ & $\begin{array}{l}0.003 * * * \\
(4.38)\end{array}$ & $\begin{array}{l}0.004 * * * \\
(6.83)\end{array}$ & $\begin{array}{l}0.007 * * * \\
(5.18)\end{array}$ & $\begin{array}{l}0.003 * * * \\
(4.38)\end{array}$ & $\begin{array}{l}0.004 * * * \\
(6.83)\end{array}$ & $\begin{array}{l}0.007 * * * \\
(5.23)\end{array}$ & $\begin{array}{l}0.003 * * * \\
(4.36)\end{array}$ \\
\hline MARRY & $\begin{array}{l}0.04 * \\
(1.95)\end{array}$ & $\begin{array}{l}0.04 \\
(0.70)\end{array}$ & $\begin{array}{l}0.01 \\
(0.63)\end{array}$ & $\begin{array}{l}0.04 * \\
(1.95)\end{array}$ & $\begin{array}{l}0.04 \\
(0.74)\end{array}$ & $\begin{array}{l}0.01 \\
(0.63)\end{array}$ & $\begin{array}{l}0.04 * \\
(1.93)\end{array}$ & $\begin{array}{l}0.04 \\
(0.72)\end{array}$ & $\begin{array}{l}0.01 \\
(0.62)\end{array}$ \\
\hline SCHOOL & $\begin{array}{l}-0.03 * * * \\
(-6.59)\end{array}$ & $\begin{array}{l}-0.03 * * * \\
(-6.14)\end{array}$ & $\begin{array}{r}-0.03 * * * \\
(-4.68)\end{array}$ & $\begin{array}{l}-0.03 * * * \\
(-6.58)\end{array}$ & $\begin{array}{l}-0.03 * * * \\
(-5.83)\end{array}$ & $\begin{array}{r}-0.03 * * * \\
(-4.69)\end{array}$ & $\begin{array}{l}-0.03 * * * \\
(-6.42)\end{array}$ & $\begin{array}{l}-0.03 * * * \\
(-5.78)\end{array}$ & $\begin{array}{c}-0.03 * * * \\
(-4.60)\end{array}$ \\
\hline UNEMP & $\begin{array}{c}0.16^{*} \\
(1.73)\end{array}$ & $\begin{array}{c}0.34^{*} \\
(1.80)\end{array}$ & $\begin{array}{l}0.10 \\
(0.98)\end{array}$ & $\begin{array}{c}0.16^{*} \\
(1.72)\end{array}$ & $\begin{array}{c}0.34^{*} \\
(1.79)\end{array}$ & $\begin{array}{l}0.10 \\
(0.97)\end{array}$ & $\begin{array}{c}0.16^{*} \\
(1.73)\end{array}$ & $\begin{array}{c}0.34 * \\
(1.81)\end{array}$ & $\begin{array}{l}0.10 \\
(0.98)\end{array}$ \\
\hline MALE & $\begin{array}{l}0.07 * * * \\
(3.17)\end{array}$ & $\begin{array}{l}0.01 \\
(0.31)\end{array}$ & $\begin{array}{l}0.11 * * * \\
(3.41)\end{array}$ & $\begin{array}{l}0.07 * * * \\
(3.15)\end{array}$ & $\begin{array}{l}0.01 \\
(0.28)\end{array}$ & $\begin{array}{l}0.11 * * * \\
(3.42)\end{array}$ & $\begin{array}{l}0.07 * * * \\
(3.15)\end{array}$ & $\begin{array}{l}0.01 \\
(0.25)\end{array}$ & $\begin{array}{l}0.11 * * * \\
(3.42)\end{array}$ \\
\hline
\end{tabular}




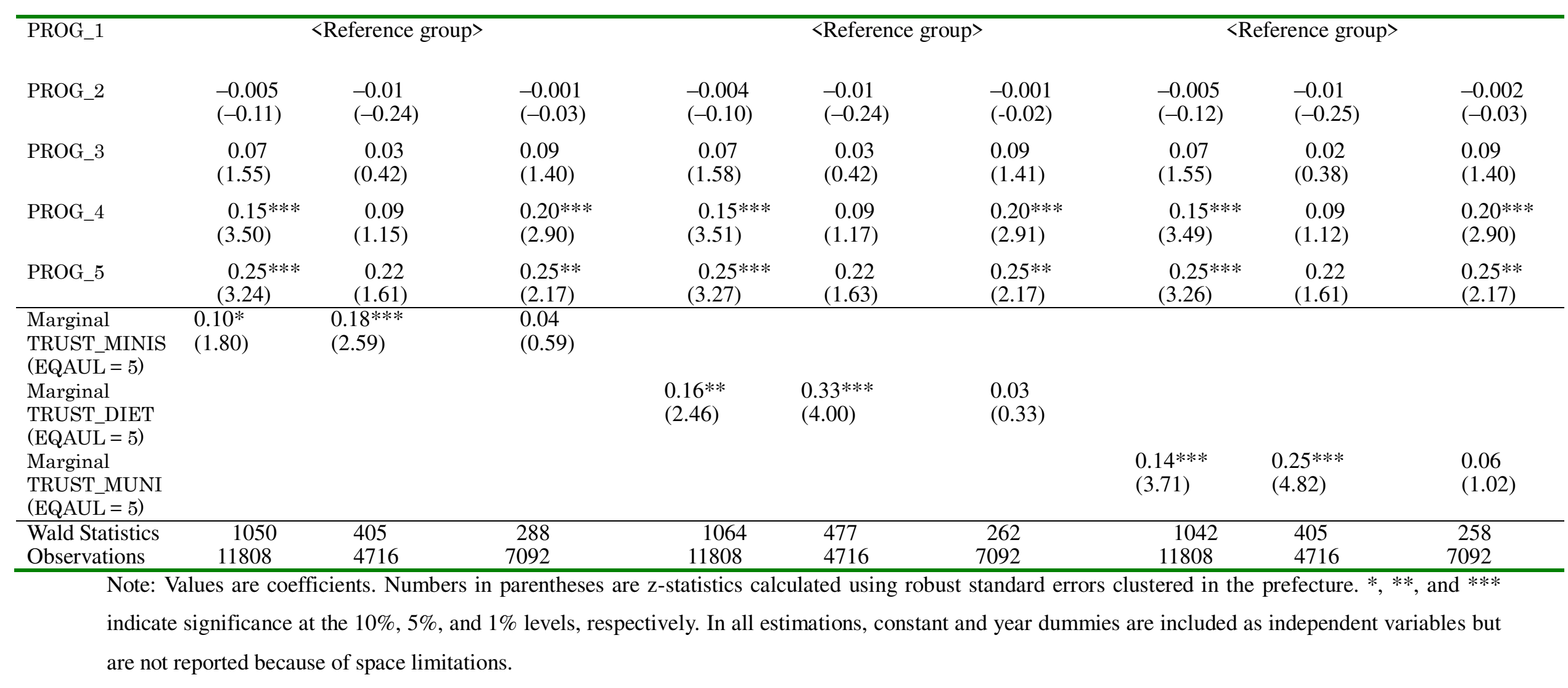


Table 5. Baseline model: dependent variable is EQUAL (ordered probit model): People live in the same prefecture they lived in at 15 years of age

\begin{tabular}{|c|c|c|c|c|c|c|c|c|c|}
\hline & $\begin{array}{l}(1) \\
\text { All }\end{array}$ & $\begin{array}{c}(2) \\
\text { High income }\end{array}$ & $\begin{array}{c}(3) \\
\text { Low income }\end{array}$ & $\begin{array}{l}(4) \\
\text { All }\end{array}$ & $\begin{array}{c}5) \\
\text { High income }\end{array}$ & $\begin{array}{c}(6) \\
\text { Low income }\end{array}$ & $\begin{array}{l}\text { (7) } \\
\text { All }\end{array}$ & $\begin{array}{l}\quad(8) \\
\text { High } \\
\text { income }\end{array}$ & $\begin{array}{c}(9) \\
\text { Low income }\end{array}$ \\
\hline \multicolumn{10}{|l|}{$\begin{array}{l}\text { Regional } \\
\text { characteristics }\end{array}$} \\
\hline TRUST_MINIS & $\begin{array}{l}0.39 \\
(1.61)\end{array}$ & $\begin{array}{l}0.72 * * \\
(2.23)\end{array}$ & $\begin{array}{l}0.17 \\
(0.65)\end{array}$ & & & & & & \\
\hline TRUST_DIET & & & & $\begin{array}{l}0.59 * * \\
(2.24)\end{array}$ & $\begin{array}{l}1.10 * * * \\
(2.85)\end{array}$ & $\begin{array}{l}0.31 \\
(0.79)\end{array}$ & & & \\
\hline TRUST_MUNI & & & & & & & $\begin{array}{l}0.60 * * * \\
(4.13)\end{array}$ & $\begin{array}{l}0.95 * * * \\
(3.94)\end{array}$ & $\begin{array}{l}0.43 * * \\
(2.10)\end{array}$ \\
\hline AVINCOM & $\begin{array}{l}-0.03 * * * \\
(-2.60)\end{array}$ & $\begin{array}{c}0.01 \\
(0.76)\end{array}$ & $\begin{array}{r}-0.06 * * * \\
(-3.39)\end{array}$ & $\begin{array}{l}-0.04 * * * \\
(-3.72)\end{array}$ & $\begin{array}{c}-0.02 \\
(-0.14)\end{array}$ & $\begin{array}{r}-0.07 * * * \\
(-4.06)\end{array}$ & $\begin{array}{l}-0.03 * * * \\
(-3.03)\end{array}$ & $\begin{array}{c}0.01 \\
(0.51)\end{array}$ & $\begin{array}{c}-0.06 * * * \\
(-3.75)\end{array}$ \\
\hline GINI & $\begin{array}{c}-0.05 \\
(-0.07)\end{array}$ & $\begin{array}{l}3.42 * * \\
(2.20)\end{array}$ & $\begin{array}{l}-1.86 \\
(-1.49)\end{array}$ & $\begin{array}{c}0.15 \\
(0.19)\end{array}$ & $\begin{array}{l}4.14 * * \\
(2.53)\end{array}$ & $\begin{array}{l}-1.78 \\
(-1.46)\end{array}$ & $\begin{array}{c}0.27 \\
(0.33)\end{array}$ & $\begin{array}{l}4.17 * * * \\
(2.80)\end{array}$ & $\begin{array}{l}-1.66 \\
(-1.36)\end{array}$ \\
\hline \multicolumn{10}{|l|}{$\begin{array}{l}\text { Individual } \\
\text { characteristics }\end{array}$} \\
\hline INCOM & $\begin{array}{l}-0.03 * * * \\
(-8.37)\end{array}$ & $\begin{array}{l}-0.02 * * * \\
(-4.74)\end{array}$ & $\begin{array}{l}-0.01 \\
(-1.02)\end{array}$ & $\begin{array}{l}-0.03 * * * \\
(-8.36)\end{array}$ & $\begin{array}{l}-0.02 * * * \\
(-4.71)\end{array}$ & $\begin{array}{l}-0.01 \\
(-1.02)\end{array}$ & $\begin{array}{l}-0.03 * * * \\
(-8.36)\end{array}$ & $\begin{array}{l}-0.02 * * * \\
(-4.71)\end{array}$ & $\begin{array}{l}-0.01 \\
(-1.03)\end{array}$ \\
\hline AGE & $\begin{array}{l}0.003 * * * \\
(4.07)\end{array}$ & $\begin{array}{l}0.007 * * * \\
(4.15)\end{array}$ & $\begin{array}{l}0.002 * * \\
(2.37)\end{array}$ & $\begin{array}{l}0.003 * * * \\
(4.03)\end{array}$ & $\begin{array}{l}0.007 * * * \\
(4.09)\end{array}$ & $\begin{array}{l}0.002 * * \\
(2.37)\end{array}$ & $\begin{array}{l}0.003 * * * \\
(4.05)\end{array}$ & $\begin{array}{l}0.007 * * * \\
(4.11)\end{array}$ & $\begin{array}{l}0.002 * * \\
(2.36)\end{array}$ \\
\hline MARRY & $\begin{array}{l}0.03 \\
(1.27)\end{array}$ & $\begin{array}{l}0.02 \\
(0.41)\end{array}$ & $\begin{array}{l}0.01 \\
(0.16)\end{array}$ & $\begin{array}{l}0.03 \\
(1.26)\end{array}$ & $\begin{array}{l}0.02 \\
(0.43)\end{array}$ & $\begin{array}{l}0.01 \\
(0.15)\end{array}$ & $\begin{array}{l}0.03 \\
(1.22)\end{array}$ & $\begin{array}{l}0.02 \\
(0.41)\end{array}$ & $\begin{array}{l}0.003 \\
(0.12)\end{array}$ \\
\hline SCHOOL & $\begin{array}{l}-0.03 * * * \\
(-5.28)\end{array}$ & $\begin{array}{l}-0.03 * * * \\
(-4.49)\end{array}$ & $\begin{array}{r}-0.02 * * * \\
(-3.51)\end{array}$ & $\begin{array}{l}-0.03 * * * \\
(-5.19)\end{array}$ & $\begin{array}{l}-0.03 * * * \\
(-4.39)\end{array}$ & $\begin{array}{r}-0.02 * * * \\
(-3.43)\end{array}$ & $\begin{array}{l}-0.03 * * * \\
(-5.11)\end{array}$ & $\begin{array}{l}-0.03 * * * \\
(-4.36)\end{array}$ & $\begin{array}{c}-0.02 * * * \\
(-3.35)\end{array}$ \\
\hline UNEMP & $\begin{array}{c}0.08 \\
(0.72)\end{array}$ & $\begin{array}{r}0.19 \\
(0.83)\end{array}$ & $\begin{array}{l}0.05 \\
(0.43)\end{array}$ & $\begin{array}{c}0.08 \\
(0.71)\end{array}$ & $\begin{array}{c}0.19 \\
(0.83)\end{array}$ & $\begin{array}{l}0.05 \\
(0.42)\end{array}$ & $\begin{array}{c}0.08 \\
(0.73)\end{array}$ & $\begin{array}{c}0.19 \\
(0.85)\end{array}$ & $\begin{array}{l}0.05 \\
(0.43)\end{array}$ \\
\hline MALE & $\begin{array}{l}0.08 * * * \\
(3.84)\end{array}$ & $\begin{array}{l}0.01 \\
(0.18)\end{array}$ & $\begin{array}{l}0.13 * * * \\
(4.03)\end{array}$ & $\begin{array}{l}0.08 * * * \\
(3.82)\end{array}$ & $\begin{array}{l}0.01 \\
(0.20)\end{array}$ & $\begin{array}{l}0.13 * * * \\
(4.02)\end{array}$ & $\begin{array}{l}0.08 * * * \\
(3.85)\end{array}$ & $\begin{array}{l}0.01 \\
(0.17)\end{array}$ & $\begin{array}{l}0.13^{* * * *} \\
(4.08)\end{array}$ \\
\hline
\end{tabular}




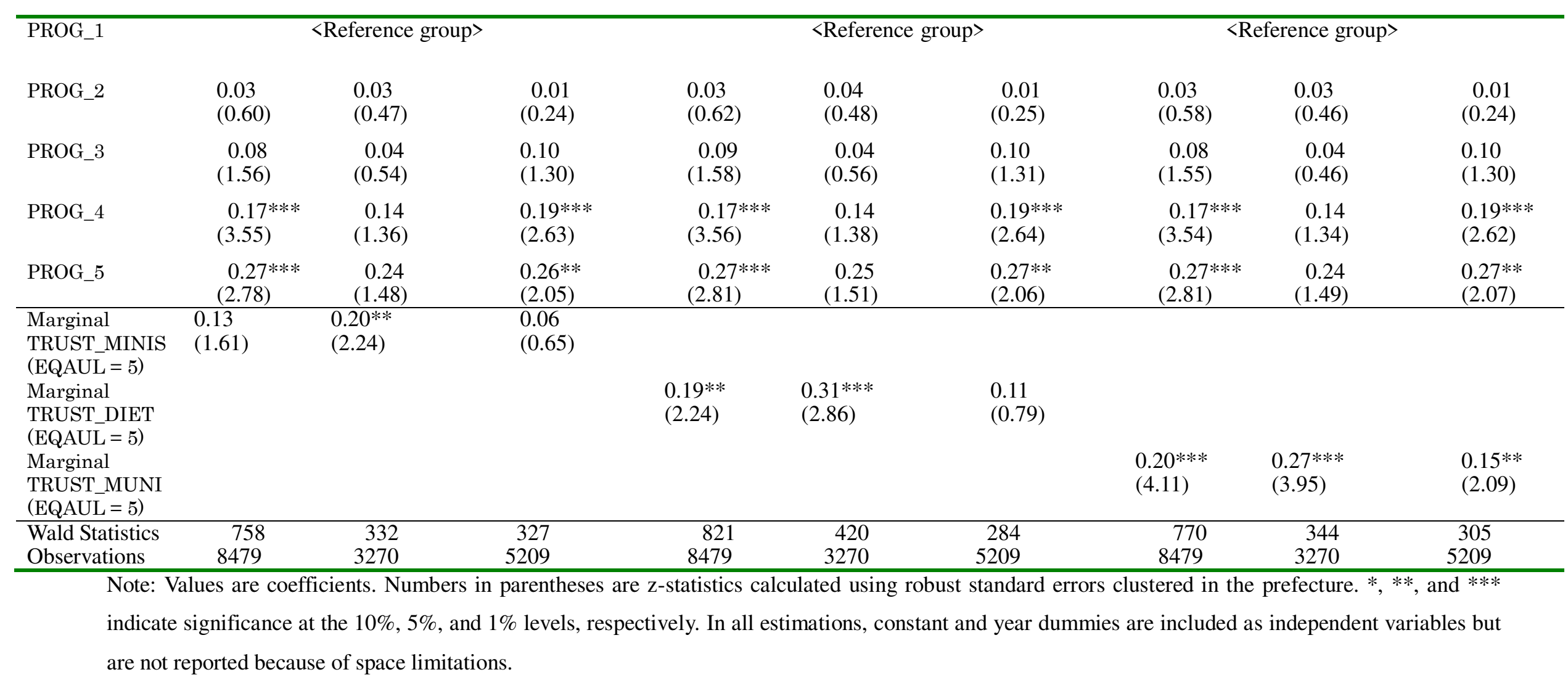


Table 6. Baseline model: dependent variable is TAX (ordered probit model)

\begin{tabular}{|c|c|c|c|c|c|c|c|c|c|}
\hline & All & $\begin{array}{c}(2) \\
\text { High income }\end{array}$ & $\begin{array}{c}\text { (3) } \\
\text { Low income }\end{array}$ & $\begin{array}{l}(4) \\
\text { All }\end{array}$ & $\begin{array}{c}(5) \\
\text { High income }\end{array}$ & $\begin{array}{c}(6) \\
\text { Low income }\end{array}$ & $\begin{array}{l}\text { (7) } \\
\text { All }\end{array}$ & $\begin{array}{l}\quad(8) \\
\text { High } \\
\text { income }\end{array}$ & $\begin{array}{c}(9) \\
\text { Low income }\end{array}$ \\
\hline \multicolumn{10}{|l|}{$\begin{array}{l}\text { Regional } \\
\text { characteristics }\end{array}$} \\
\hline TRUST_MINIS & $\begin{array}{l}-0.44^{*} \\
(-1.92)\end{array}$ & $\begin{array}{l}-0.94^{*} \\
(-1.93)\end{array}$ & $\begin{array}{l}-0.13 \\
(-0.42)\end{array}$ & & & & & & \\
\hline TRUST_DIET & & & & $\begin{array}{l}-0.45 \\
(-1.53)\end{array}$ & $\begin{array}{l}1.22 * * * \\
(-2.89)\end{array}$ & $\begin{array}{l}0.25 \\
(0.60)\end{array}$ & & & \\
\hline TRUST_MUNI & & & & & & & $\begin{array}{l}-0.33 \\
(-1.55)\end{array}$ & $\begin{array}{l}-0.99 * * * \\
(-3.03)\end{array}$ & $\begin{array}{l}0.23 \\
(0.67)\end{array}$ \\
\hline AVINCOM & $\begin{array}{l}-0.01 \\
(-0.73)\end{array}$ & $\begin{array}{l}-0.03 \\
(-1.17)\end{array}$ & $\begin{array}{l}0.01 \\
\quad(0.59)\end{array}$ & $\begin{array}{l}-0.003 \\
(-0.24)\end{array}$ & $\begin{array}{l}-0.02 \\
(-0.92)\end{array}$ & $\begin{array}{l}0.02 \\
\quad(0.88)\end{array}$ & $\begin{array}{l}-0.01 \\
(-0.42)\end{array}$ & $\begin{array}{l}-0.03 \\
(-1.22)\end{array}$ & $\begin{array}{l}0.02 \\
\quad(0.91)\end{array}$ \\
\hline GINI & $\begin{array}{c}-0.61 \\
(-0.57)\end{array}$ & $\begin{array}{l}0.70 \\
(0.57)\end{array}$ & $\begin{array}{l}-1.90 \\
(-1.35)\end{array}$ & $\begin{array}{c}-0.77 \\
(-0.71)\end{array}$ & $\begin{array}{l}-0.18 \\
(-0.13)\end{array}$ & $\begin{array}{l}-1.73 \\
(-1.26)\end{array}$ & $\begin{array}{c}-0.70 \\
(-0.66)\end{array}$ & $\begin{array}{l}0.06 \\
(0.06)\end{array}$ & $\begin{array}{l}-1.73 \\
(-1.25)\end{array}$ \\
\hline \multicolumn{10}{|l|}{$\begin{array}{l}\text { Individual } \\
\text { characteristics }\end{array}$} \\
\hline INCOM & $\begin{array}{l}0.01 * * * \\
(2.97)\end{array}$ & $\begin{array}{l}0.01 * * * \\
(3.47)\end{array}$ & $\begin{array}{l}-0.01 \\
(-1.29)\end{array}$ & $\begin{array}{l}0.01 * * * \\
(2.96)\end{array}$ & $\begin{array}{l}0.01 * * * \\
(3.52)\end{array}$ & $\begin{array}{l}-0.01 \\
(-1.29)\end{array}$ & $\begin{array}{l}0.01 * * * \\
(2.97)\end{array}$ & $\begin{array}{l}0.01 * * * \\
(3.49)\end{array}$ & $\begin{array}{l}-0.01 \\
(-1.29)\end{array}$ \\
\hline AGE & $\begin{array}{c}-0.004 * * * \\
(-3.76)\end{array}$ & $\begin{array}{l}0.0001 \\
(0.05)\end{array}$ & $\begin{array}{l}-0.01 * * * \\
(-6.20)\end{array}$ & $\begin{array}{c}-0.004 * * * \\
(-0.80)\end{array}$ & $\begin{array}{l}0.0001 \\
(0.05)\end{array}$ & $\begin{array}{l}-0.01 * * * \\
(-6.16)\end{array}$ & $\begin{array}{c}-0.004 * * * \\
(-3.80)\end{array}$ & $\begin{array}{l}0.0001 \\
(0.05)\end{array}$ & $\begin{array}{l}-0.01 * * * \\
(-6.20)\end{array}$ \\
\hline MARRY & $\begin{array}{l}0.04 \\
(1.42)\end{array}$ & $\begin{array}{l}0.09 \\
(1.44)\end{array}$ & $\begin{array}{l}0.04 \\
(1.19)\end{array}$ & $\begin{array}{l}0.04 \\
(1.40)\end{array}$ & $\begin{array}{l}0.09 \\
(1.40)\end{array}$ & $\begin{array}{l}0.04 \\
(1.16)\end{array}$ & $\begin{array}{l}0.04 \\
(1.40)\end{array}$ & $\begin{array}{l}0.09 \\
(1.44)\end{array}$ & $\begin{array}{l}0.04 \\
(1.15)\end{array}$ \\
\hline SCHOOL & $\begin{array}{l}-0.02 * * * \\
(-3.44)\end{array}$ & $\begin{array}{c}-0.0001 \\
(-0.001)\end{array}$ & $\begin{array}{r}-0.03 * * * \\
(-3.90)\end{array}$ & $\begin{array}{l}-0.02 * * * \\
(-3.44)\end{array}$ & $\begin{array}{l}-0.001 \\
(-0.010)\end{array}$ & $\begin{array}{r}-0.03 * * * \\
(-3.82)\end{array}$ & $\begin{array}{l}-0.02 * * * \\
(-3.49)\end{array}$ & $\begin{array}{c}-0.001 \\
(-0.22)\end{array}$ & $\begin{array}{c}-0.03 * * * \\
(-3.81)\end{array}$ \\
\hline UNEMP & $\begin{array}{c}0.03 \\
(0.32)\end{array}$ & $\begin{array}{c}-0.23 \\
(-1.15)\end{array}$ & $\begin{array}{l}0.14 \\
(1.25)\end{array}$ & $\begin{array}{c}0.03 \\
(0.34)\end{array}$ & $\begin{array}{c}-0.24 \\
(-1.16)\end{array}$ & $\begin{array}{l}0.14 \\
(1.28)\end{array}$ & $\begin{array}{c}0.03 \\
(0.34)\end{array}$ & $\begin{array}{c}-0.24 \\
(-1.15)\end{array}$ & $\begin{array}{l}0.14 \\
(1.29)\end{array}$ \\
\hline MALE & $\begin{array}{l}0.02 \\
(0.65)\end{array}$ & $\begin{array}{l}0.01 \\
(0.31)\end{array}$ & $\begin{array}{l}0.02 \\
(0.73)\end{array}$ & $\begin{array}{l}0.02 \\
(0.66)\end{array}$ & $\begin{array}{l}0.01 \\
(0.33)\end{array}$ & $\begin{array}{l}0.02 \\
(0.72)\end{array}$ & $\begin{array}{l}0.02 \\
(0.65)\end{array}$ & $\begin{array}{l}0.01 \\
(0.35)\end{array}$ & $\begin{array}{l}0.02 \\
(0.73)\end{array}$ \\
\hline
\end{tabular}




\begin{tabular}{|c|c|c|c|c|c|c|c|c|c|}
\hline \multirow{2}{*}{$\begin{array}{l}\text { PROG_1 } \\
\text { PROG_2 }\end{array}$} & \multicolumn{3}{|c|}{$\langle$ Reference group $\rangle$} & \multicolumn{3}{|c|}{$\langle$ Reference group $>$} & \multicolumn{3}{|c|}{$<$ Reference group $>$} \\
\hline & $\begin{array}{l}-0.009 \\
(-0.16)\end{array}$ & $\begin{array}{l}0.02 \\
(0.29)\end{array}$ & $\begin{array}{l}-0.01 \\
(-0.26)\end{array}$ & $\begin{array}{l}-0.01 \\
(-0.17)\end{array}$ & $\begin{array}{l}0.02 \\
(0.31)\end{array}$ & $\begin{array}{l}-0.01 \\
(-0.26)\end{array}$ & $\begin{array}{l}-0.009 \\
(-0.16)\end{array}$ & $\begin{array}{l}0.02 \\
(0.32)\end{array}$ & $\begin{array}{l}-0.01 \\
(-0.26)\end{array}$ \\
\hline PROG_3 & $\begin{array}{l}0.18 * * * \\
(3.74)\end{array}$ & $\begin{array}{l}0.21 * * \\
(2.48)\end{array}$ & $\begin{array}{l}0.17 * * * \\
(2.84)\end{array}$ & $\begin{array}{l}0.18 * * * \\
(3.72)\end{array}$ & $\begin{array}{l}0.21 * * \\
(2.50)\end{array}$ & $\begin{array}{l}0.17 * * * \\
(2.88)\end{array}$ & $\begin{array}{l}0.18 * * * \\
(3.76)\end{array}$ & $\begin{array}{l}0.21 * * \\
(2.55)\end{array}$ & $\begin{array}{l}0.17 * * * \\
(2.87)\end{array}$ \\
\hline PROG_4 & $\begin{array}{l}0.16^{* * * *} \\
(3.37)\end{array}$ & $\begin{array}{l}0.19 * * \\
(2.21)\end{array}$ & $\begin{array}{l}0.16^{* * *} \\
(2.42)\end{array}$ & $\begin{array}{l}0.16^{* * * *} \\
(3.37)\end{array}$ & $\begin{array}{l}0.19 * * \\
(2.23)\end{array}$ & $\begin{array}{l}0.16^{* * *} \\
(2.43)\end{array}$ & $\begin{array}{l}0.16^{* * * *} \\
(3.42)\end{array}$ & $\begin{array}{l}0.19 * * \\
(2.30)\end{array}$ & $\begin{array}{l}0.16^{* * *} \\
(2.42)\end{array}$ \\
\hline PROG_5 & $\begin{array}{l}0.52 * * * \\
(5.01)\end{array}$ & $\begin{array}{l}0.76^{* * * *} \\
(4.06)\end{array}$ & $\begin{array}{l}0.36 \text { *** } \\
(3.50)\end{array}$ & $\begin{array}{l}0.52 * * * \\
(5.01)\end{array}$ & $\begin{array}{l}0.76 * * * \\
(4.07)\end{array}$ & $\begin{array}{l}0.37 * * * \\
(3.52)\end{array}$ & $\begin{array}{l}0.52 * * * \\
(5.02)\end{array}$ & $\begin{array}{l}0.76^{* * * *} \\
(4.08)\end{array}$ & $\begin{array}{l}0.37 * * * \\
(3.50)\end{array}$ \\
\hline $\begin{array}{l}\text { Marginal } \\
\text { TRUST_MINIS } \\
(\text { EQAUL = 5) }\end{array}$ & $\begin{array}{l}-0.17 * \\
(-1.92)\end{array}$ & $\begin{array}{l}-0.29 * \\
(-1.93)\end{array}$ & $\begin{array}{l}-0.05 \\
(-0.42)\end{array}$ & & & & & & \\
\hline $\begin{array}{l}\text { Marginal } \\
\text { TRUST_DIET } \\
(\text { EQAUL = 5) }\end{array}$ & & & & $\begin{array}{l}-0.17 \\
(-1.54)\end{array}$ & $\begin{array}{l}-0.47 * * * \\
(-2.79)\end{array}$ & $\begin{array}{l}0.10 \\
(0.60)\end{array}$ & & & \\
\hline $\begin{array}{l}\text { Marginal } \\
\text { TRUST_MUNI } \\
(\text { EQAUL = 5) }\end{array}$ & & & & & & & $\begin{array}{l}-0.13 \\
(-1.56)\end{array}$ & $\begin{array}{l}-0.39 * * * \\
(-3.05)\end{array}$ & $\begin{array}{l}0.09 \\
(0.67)\end{array}$ \\
\hline Wald Statistics & 201 & 134 & 158 & 162 & 144 & 156 & 179 & 125 & 165 \\
\hline Observations & 7794 & 3512 & 4282 & 7794 & 3512 & 4282 & 7794 & 3512 & 4282 \\
\hline
\end{tabular}


Table 7. Baseline model: dependent variable is TAX (ordered probit model): People live in the same prefecture they lived in at 15 years of age

\begin{tabular}{|c|c|c|c|c|c|c|c|c|c|}
\hline & $\begin{array}{l}(1) \\
\text { All }\end{array}$ & $\begin{array}{c}(2) \\
\text { High income }\end{array}$ & $\begin{array}{c}(3) \\
\text { Low income }\end{array}$ & $\begin{array}{l}(4) \\
\text { All }\end{array}$ & $\begin{array}{c}5) \\
\text { High income }\end{array}$ & $\begin{array}{c}(6) \\
\text { Low income }\end{array}$ & $\begin{array}{l}(7) \\
\text { All }\end{array}$ & $\begin{array}{l}\quad(8) \\
\text { High } \\
\text { income }\end{array}$ & $\begin{array}{c}(9) \\
\text { Low income }\end{array}$ \\
\hline \multicolumn{10}{|l|}{$\begin{array}{l}\text { Regional } \\
\text { characteristics }\end{array}$} \\
\hline TRUST_MINIS & $\begin{array}{l}-0.41 \\
(-0.32)\end{array}$ & $\begin{array}{l}-0.76^{*} \\
(-1.67)\end{array}$ & $\begin{array}{l}-0.11 \\
(-0.34)\end{array}$ & & & & & & \\
\hline TRUST_DIET & & & & $\begin{array}{l}-0.44 \\
(-1.12)\end{array}$ & $\begin{array}{l}1.26 * * * \\
(-2.60)\end{array}$ & $\begin{array}{l}0.44 \\
(0.80)\end{array}$ & & & \\
\hline TRUST_MUNI & & & & & & & $\begin{array}{l}-0.28 \\
(-0.98)\end{array}$ & $\begin{array}{l}-1.02 * * * \\
(-2.79)\end{array}$ & $\begin{array}{l}0.42 \\
(1.04)\end{array}$ \\
\hline AVINCOM & $\begin{array}{l}-0.01 \\
(-0.92)\end{array}$ & $\begin{array}{l}-0.05 \\
(-1.53)\end{array}$ & $\begin{array}{l}-0.01 \\
(-0.22)\end{array}$ & $\begin{array}{l}-0.01 \\
(-0.55)\end{array}$ & $\begin{array}{l}-0.03 \\
(-1.16)\end{array}$ & $\begin{array}{l}0.01 \\
(0.67)\end{array}$ & $\begin{array}{l}-0.01 \\
(-0.67)\end{array}$ & $\begin{array}{l}-0.04 \\
(-1.44)\end{array}$ & $\begin{array}{l}0.02 \\
\quad(0.83)\end{array}$ \\
\hline GINI & $\begin{array}{c}-0.65 \\
(-0.55)\end{array}$ & $\begin{array}{l}1.34 \\
(0.91)\end{array}$ & $\begin{array}{l}-2.15 \\
(-1.20)\end{array}$ & $\begin{array}{c}-0.79 \\
(-0.65)\end{array}$ & $\begin{array}{l}0.46 \\
(0.28)\end{array}$ & $\begin{array}{l}-2.14 \\
(-1.35)\end{array}$ & $\begin{array}{c}-0.74 \\
(-0.63)\end{array}$ & $\begin{array}{l}0.59 \\
(0.38)\end{array}$ & $\begin{array}{l}-2.08 \\
(-1.30)\end{array}$ \\
\hline \multicolumn{10}{|l|}{$\begin{array}{l}\text { Individual } \\
\text { characteristics }\end{array}$} \\
\hline INCOM & $\begin{array}{l}0.01^{*} \\
(1.67)\end{array}$ & $\begin{array}{l}0.01 * * * \\
(3.30)\end{array}$ & $\begin{array}{l}-0.01 \\
(-1.32)\end{array}$ & $\begin{array}{l}0.01^{*} \\
(1.66)\end{array}$ & $\begin{array}{l}0.01 * * * \\
(3.33)\end{array}$ & $\begin{array}{l}-0.02^{*} \\
(-1.70)\end{array}$ & $\begin{array}{l}0.01^{*} \\
(1.67)\end{array}$ & $\begin{array}{l}0.01 * * * \\
(3.31)\end{array}$ & $\begin{array}{l}-0.02^{*} \\
(-1.70)\end{array}$ \\
\hline AGE & $\begin{array}{c}-0.003 * * * \\
(-2.59)\end{array}$ & $\begin{array}{l}0.0002 \\
(0.10)\end{array}$ & $\begin{array}{l}-0.01 * * * \\
(-4.28)\end{array}$ & $\begin{array}{c}-0.003 * * * \\
(-2.62)\end{array}$ & $\begin{array}{l}0.0002 \\
(0.12)\end{array}$ & $\begin{array}{l}-0.01 * * * \\
(-4.12)\end{array}$ & $\begin{array}{c}-0.003 * * * \\
(-2.61)\end{array}$ & $\begin{array}{l}0.0002 \\
(0.13)\end{array}$ & $\begin{array}{l}-0.01 * * * \\
(-4.12)\end{array}$ \\
\hline MARRY & $\begin{array}{l}0.06^{*} \\
(1.81)\end{array}$ & $\begin{array}{l}0.06 \\
(1.04)\end{array}$ & $\begin{array}{l}0.07 * \\
(1.82)\end{array}$ & $\begin{array}{l}0.06^{*} \\
(1.80)\end{array}$ & $\begin{array}{l}0.06 \\
(1.04)\end{array}$ & $\begin{array}{l}0.08^{*} \\
(1.87)\end{array}$ & $\begin{array}{l}0.06^{*} \\
(1.80)\end{array}$ & $\begin{array}{l}0.06 \\
(1.08)\end{array}$ & $\begin{array}{l}0.07 * \\
(1.86)\end{array}$ \\
\hline SCHOOL & $\begin{array}{l}-0.02 * * * \\
(-2.83)\end{array}$ & $\begin{array}{l}-0.004 \\
(-0.48)\end{array}$ & $\begin{array}{r}-0.02 * * * \\
(-2.56)\end{array}$ & $\begin{array}{l}-0.02 * * * \\
(-2.82)\end{array}$ & $\begin{array}{l}-0.004 \\
(-0.53)\end{array}$ & $\begin{array}{r}-0.02 * * * \\
(-2.57)\end{array}$ & $\begin{array}{l}-0.02 * * * \\
(-2.83)\end{array}$ & $\begin{array}{c}-0.005 \\
(-0.61)\end{array}$ & $\begin{array}{c}-0.02 * * * \\
(-2.52)\end{array}$ \\
\hline UNEMP & $\begin{array}{c}0.03 \\
(0.28)\end{array}$ & $\begin{array}{c}-0.22 \\
(-0.96)\end{array}$ & $\begin{array}{l}0.03 \\
(0.25)\end{array}$ & $\begin{array}{c}0.03 \\
(0.30)\end{array}$ & $\begin{array}{c}-0.23 \\
(-0.98)\end{array}$ & $\begin{array}{l}0.13 \\
(1.00)\end{array}$ & $\begin{array}{c}0.03 \\
(0.30)\end{array}$ & $\begin{array}{c}-0.23 \\
(-0.98)\end{array}$ & $\begin{array}{l}0.13 \\
(1.02)\end{array}$ \\
\hline MALE & $\begin{array}{l}0.01 \\
(0.28)\end{array}$ & $\begin{array}{l}-0.02 \\
(-0.59)\end{array}$ & $\begin{array}{l}0.01 \\
(0.82)\end{array}$ & $\begin{array}{l}0.01 \\
(0.33)\end{array}$ & $\begin{array}{l}-0.03 \\
(-0.62)\end{array}$ & $\begin{array}{l}0.04 \\
(1.02)\end{array}$ & $\begin{array}{l}0.01 \\
(0.33)\end{array}$ & $\begin{array}{l}-0.02 \\
(-0.61)\end{array}$ & $\begin{array}{l}0.04 \\
(1.04)\end{array}$ \\
\hline
\end{tabular}




\begin{tabular}{|c|c|c|c|c|c|c|c|c|c|}
\hline \multirow{2}{*}{$\begin{array}{l}\text { PROG_1 } \\
\text { PROG_2 }\end{array}$} & \multicolumn{3}{|c|}{$\langle$ Reference group $>$} & \multicolumn{3}{|c|}{$<$ Reference group $>$} & \multicolumn{3}{|c|}{$<$ Reference group $>$} \\
\hline & $\begin{array}{l}-0.008 \\
(-0.13)\end{array}$ & $\begin{array}{l}-0.01 \\
(-0.15)\end{array}$ & $\begin{array}{l}0.01 \\
(0.07)\end{array}$ & $\begin{array}{l}-0.01 \\
(-0.15)\end{array}$ & $\begin{array}{l}-0.01 \\
(-0.15)\end{array}$ & $\begin{array}{l}0.004 \\
(0.06)\end{array}$ & $\begin{array}{l}-0.009 \\
(-0.14)\end{array}$ & $\begin{array}{l}-0.01 \\
(-0.14)\end{array}$ & $\begin{array}{l}0.003 \\
(0.04)\end{array}$ \\
\hline PROG_3 & $\begin{array}{l}0.20 * * * \\
(3.71)\end{array}$ & $\begin{array}{l}0.19 * * \\
(2.11)\end{array}$ & $\begin{array}{l}0.23 * * * \\
(3.31)\end{array}$ & $\begin{array}{l}0.20 * * * \\
(3.70)\end{array}$ & $\begin{array}{l}0.19 * * \\
(2.10)\end{array}$ & $\begin{array}{l}0.22 * * * \\
(3.34)\end{array}$ & $\begin{array}{l}0.21 * * * \\
(3.74)\end{array}$ & $\begin{array}{l}0.19 * * \\
(2.16)\end{array}$ & $\begin{array}{l}0.22 * * * \\
(3.32)\end{array}$ \\
\hline PROG_4 & $\begin{array}{l}0.18 * * * \\
(2.61)\end{array}$ & $\begin{array}{l}0.16^{*} \\
(1.73)\end{array}$ & $\begin{array}{l}0.23 * * * \\
(2.63)\end{array}$ & $\begin{array}{l}0.18^{* * * *} \\
(2.61)\end{array}$ & $\begin{array}{c}0.16^{*} \\
(1.73)\end{array}$ & $\begin{array}{l}0.20 * * \\
(2.26)\end{array}$ & $\begin{array}{l}0.18 * * * \\
(2.64)\end{array}$ & $\begin{array}{c}0.17 * \\
(1.82)\end{array}$ & $\begin{array}{l}0.19 * * \\
(2.24)\end{array}$ \\
\hline PROG_5 & $\begin{array}{l}0.51 * * * \\
(4.83)\end{array}$ & $\begin{array}{l}0.74 * * * \\
(4.09)\end{array}$ & $\begin{array}{l}0.46^{* * * *} \\
(3.28)\end{array}$ & $\begin{array}{l}0.51 * * * \\
(4.85)\end{array}$ & $\begin{array}{l}0.73 * * * \\
(4.08)\end{array}$ & $\begin{array}{l}0.39 * * * \\
(3.11) \\
\end{array}$ & $\begin{array}{l}0.52 * * * \\
(4.84)\end{array}$ & $\begin{array}{l}0.73 * * * \\
(4.10)\end{array}$ & $\begin{array}{l}0.39 * * * \\
(3.09)\end{array}$ \\
\hline $\begin{array}{l}\text { Marginal } \\
\text { TRUST_MINIS } \\
(\text { EQAUL = 5) }\end{array}$ & $\begin{array}{l}-0.16 \\
(-1.33)\end{array}$ & $\begin{array}{l}-0.29 * \\
(-1.67)\end{array}$ & $\begin{array}{l}-0.04 \\
(-0.34)\end{array}$ & & & & & & \\
\hline $\begin{array}{l}\text { Marginal } \\
\text { TRUST_DIET } \\
(\text { EQAUL = 5) }\end{array}$ & & & & $\begin{array}{l}-0.17 \\
(-1.12)\end{array}$ & $\begin{array}{l}-0.49 * * * \\
(-2.61)\end{array}$ & $\begin{array}{l}0.17 \\
(0.80)\end{array}$ & & & \\
\hline $\begin{array}{l}\text { Marginal } \\
\text { TRUST_MUNI } \\
(\text { EQAUL = 5) }\end{array}$ & & & & & & & $\begin{array}{l}-0.11 \\
(-0.99)\end{array}$ & $\begin{array}{l}-0.39 * * * \\
(-2.81)\end{array}$ & $\begin{array}{l}0.16 \\
(1.04)\end{array}$ \\
\hline $\begin{array}{l}\text { Wald Statistics } \\
\text { Observations }\end{array}$ & $\begin{array}{r}164 \\
5606\end{array}$ & $\begin{array}{r}87 \\
2479\end{array}$ & $\begin{array}{r}130 \\
2844\end{array}$ & $\begin{array}{r}164 \\
5606\end{array}$ & $\begin{array}{r}103 \\
2479\end{array}$ & $\begin{array}{r}173 \\
2844\end{array}$ & $\begin{array}{r}165 \\
5606\end{array}$ & $\begin{array}{r}102 \\
2479\end{array}$ & $\begin{array}{r}173 \\
2844\end{array}$ \\
\hline
\end{tabular}

Note: Values are coefficients. Numbers in parentheses are z-statistics calculated using robust standard errors clustered in the prefecture. *,**, and $* * *$ indicate significance at the $10 \%, 5 \%$, and $1 \%$ levels, respectively. In all estimations, constant and year dummies are included as independent variables but are not reported because of space limitations. 